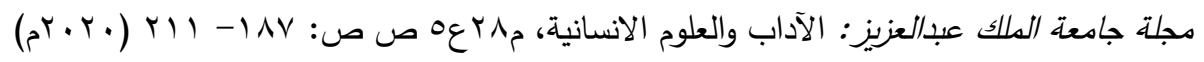

$$
\begin{aligned}
& \text { DOI:10.4197/Art.28-5.7 }
\end{aligned}
$$

\title{
القراءاتُ القرآنيةُ والتقعيدُ النحْوَيّ؛ دراسة تحليلية نقدية
}

\author{
د. دامد صبحي محمد حامد "السيوطي" \\ جامعة الملك عبد العزيز - كلية الآداب والعلوم الإنسانية
}

مستخلص. عمل هذا البحث على دراسة واقع القراءات القرآنية ودورها في التقعيد النحوي، وبيان مدى التناقض الذي وقع فيه النحاة بين موقفهم النظري من الاحتجاج بالقراءات وموقفهم التطبيقي من رد بعض القراءات، وتضعيف البعض، وتقديم الشعر والأقيسة العقلية عليى القراءات القرآنية في عملية التقعيد النحوي. ثم بين البحث الفائدة التي أكسبتها القراءات القرآنية للقاعدة النحوية ومدى الرحابة والسعة التي عادت على القعاعدة النحوية واللغة عموما من الاعتماد على القراءات القرآنية، وبيان مدى تواجد القراءات القرآنية في كتب النحو.

تتطلق منها من السماع والإجماع والقياس والعلة

\section{المقدمة}

فقضية التقعيد النحوي من أهم القضايا التي شغلت والاستصحاب، ويأتي السماع في مقدمتها وأهمها، بال اللغويين عامة والنحويين خاصة؛ لأنها هي ويأتي القرآن الكريم وقراءاته في مقدمة السماع وأول الأساس التي تقوم عليه قواعدهم؛ لذلك اهتم بهال

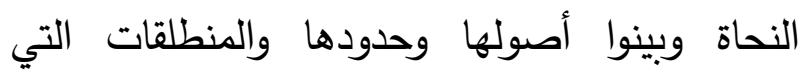


للقراءات القرآنية في التقعيد النحوي واعتمد عليها أكثر من الشعر أو الأقيسة المنطقية في التقعيد وبناء

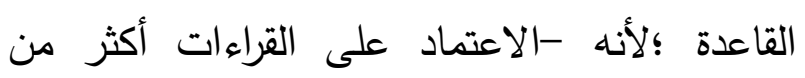
الشعر والأقيسة العقلية- سيعطي القاعدة النحوية رحابة وسعة كبيرة في شمول عدد كبير من النماذج

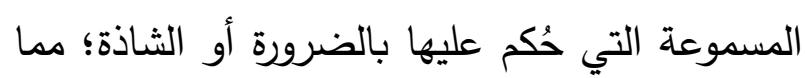
يخلص النحو العربي من خلافات كبيرة أثقلت كاهله وصرفت الجهود عن البحث عن الأسرار الدلالية في النصوص إلى محاولة إثبات صحة النص وموافقته النه للعربية ؛ ولذلك عنونت الدراسة بـ "القراءات القرآنية والتقعيد النحوي؛ دراسة تحليلية نقدية" لتحليل واقع القراءات القرآنية في التقعيد النحوي ودراسته دراسة

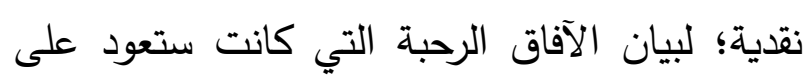

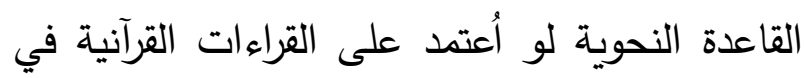
التقعيد النحوي بصورة أكبر مما هي عليه.

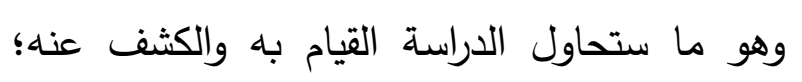
ولذلك تأتي الدراسة في المحاور التالية:

$$
\text { محاور الدراسة }
$$

المحور الأول: وفيه النقاط التالية:

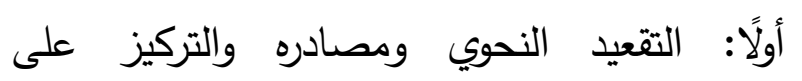
السماع. ثانيًا: نماذج تطبيقية لرفض النحاة لبعض القراءات القرآنية، وتتاقض ذلك مع موقفهم النظري بقبولها.

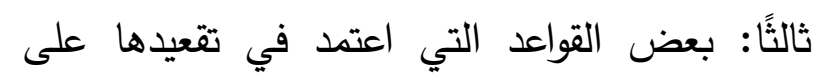

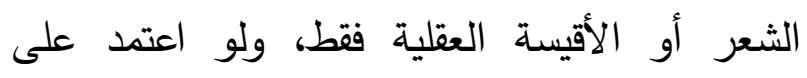
القراءات القرآنية لزال الجدل والخلاف.

\section{مشكلة الاراسة}

رغم تصريح النحاة وإجماعهم على أن القرآن الكريم

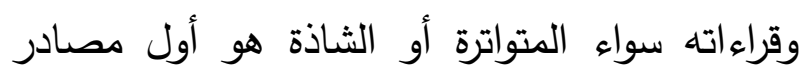

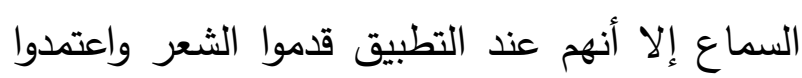
عليه في بناء قواعداهم، وكذلك أقيستهم المنطقية،

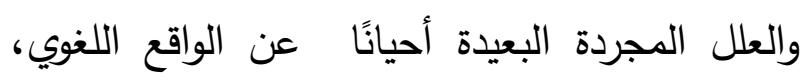
ويكفي دليلًا على ذلك إلقاء نظرة على كتب التقعيد النحوي ونسبة الثواهد الشعرية فيها مقارنة بالثواهد القرآنية-كما سيظهر في الدراسة- بل اعتمدوا على لئى

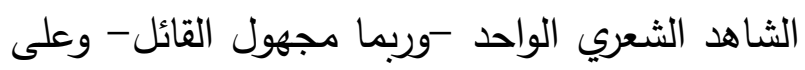
العلل المنطقية، وردوا بعض القراءات الثاذة بل لتبل والمتواترة أيضا !!!! أهمية الدراستة: تأتي هذه الدراسة حول دور القرآن الكريم بقراءاته

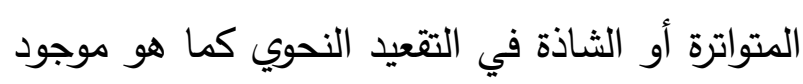
بالفعل من خلال رصد واقع اعتماد النحاة الفعلي التطبيقي على القرآن الكريم بقراءاته مقارنة بالشعر

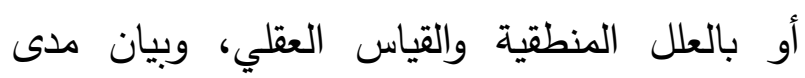

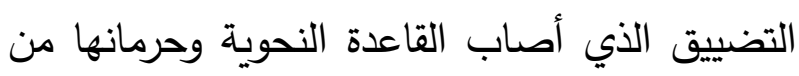

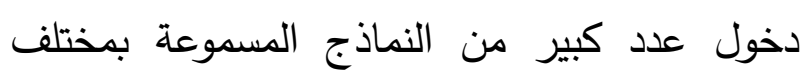

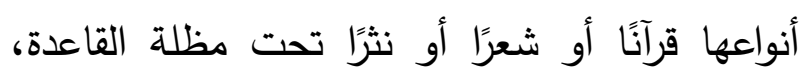

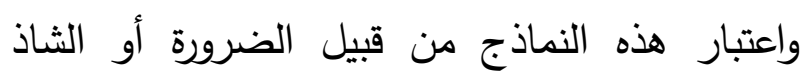
،والدخول في جدال طويل حول تخريجها وبيان وجه صحتها وتأويلها؛ مما أثقل كاهل النحو العربي. ثم بيان الفائدة التي كانت ستعود على النحو عامة وعلى القاعدة النحوية خاصة لو أفسح المجال 
المحور الثاني: مظاهر اهتمام النحاة بالقراءات معنى السماع:

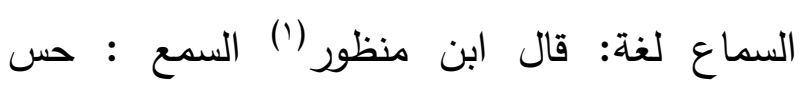

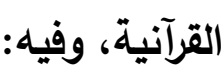

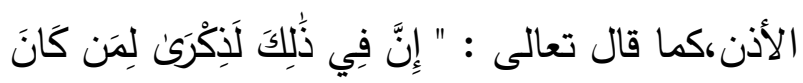

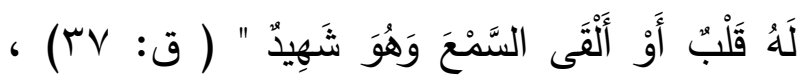

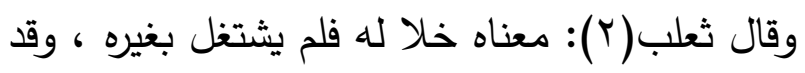

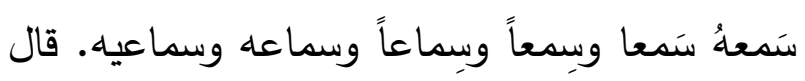

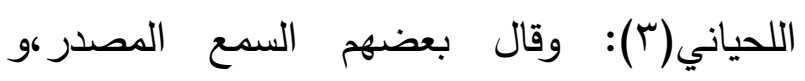

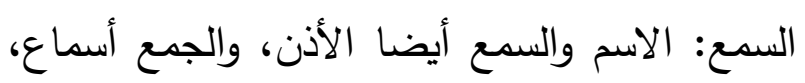
وقال ابن السكيت(؟): السمع سمع الإنسان وغيره يكون واحدًا وجمعا. السماع اصطلاحًا: عرّف ابن الأنباري (ن) السماع بقوله: هو كلام

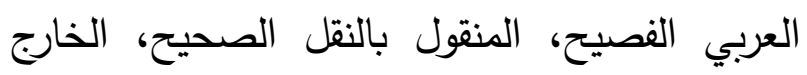
عن حد القلة إلى حد الكثرة، فخرج عنه ما جاء في كلام غير العرب من المولدين، وما شذ من كلامهم

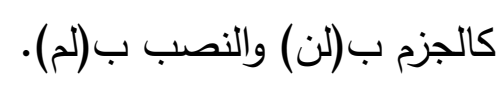

وعرّف السيوطي بعد ذلك السماع تعريفًا يُعد أكثر ولَّر شمولًا، حدّد فيه ينابيع السماع ومصادره فعرّفه بقوله:

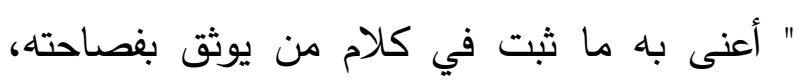
فشمل كلام الله تعالى، وهو القرآن الكريم، وكلام نبيه

(') لسان العرب، ابن منظور، الطبعة الأولى، الجزء V، لو، مطبعة الأميرية،

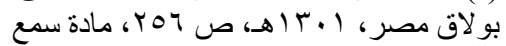

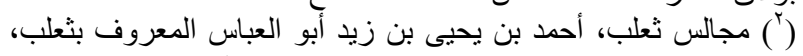

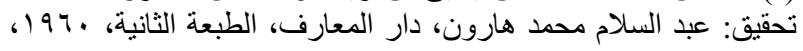

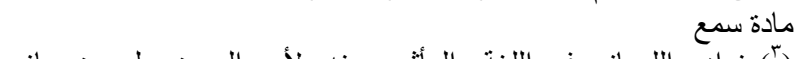

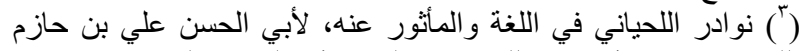

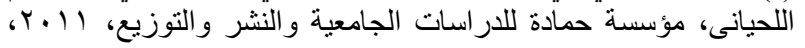

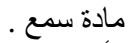
(أ) إصلاح المنطق، لابن السكيت، المحقق: أحمد محمد شاكر و وعبد

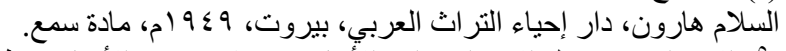

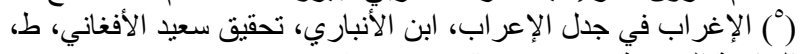

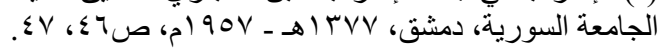

أولًا: الكتب التي خصرانه، وهـ: لتوجيه القراءات سواء المتواترة أو الثاذة، وكتب معاني القرآن وإعرابه.

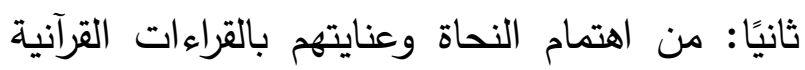
أنهم استشهدوا بها في مواطن الخلاف النحوي. المحور الثالث بيان أثر القراءات القرآنية في التقعيد النحوى

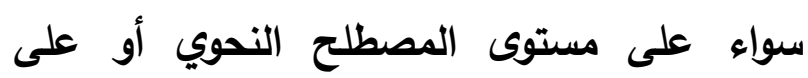
مستوى الالالة التي أضافتها للقاعدة. المحور الأول أولًا: التقعيد النحوي ومصادره والتركيز على

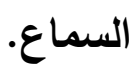
اعتمد التقعيد اللغوي عامة، والنحوي خاصة على مصادر متتوعة من السماع والإجماع والقياس والاستصحاب. ويعد السماع اللغوي واحدًا من أهم مصادر التقعيد النحوي، وهو الأساس الذي بنيت عليه أغلب قواعد اللغة، وهو الطريق الطبيعى لمعرفة اللغة وبيان

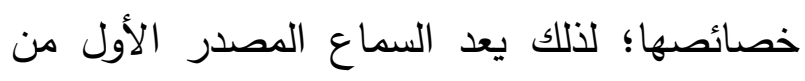
مصادر اللغة، وما عداه متفرع عنه، ومبني عليه

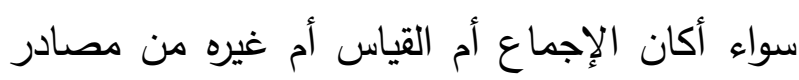
التقعيد.

وهذا يدعونا إلى التساؤل عن معرفة معنى السماع؟

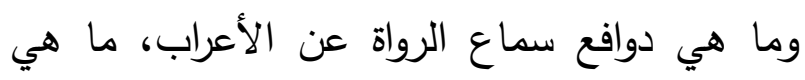
حدود السماع عن الأعراب؟ 
ويرى بروكلمان(r) أن أهم دوافع التقعيد اللغوي هي الخلافات اللغوية بين لهجات القبائل العربية بعضها

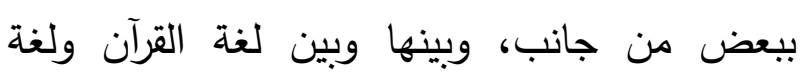
الشعر من جانب آخر.

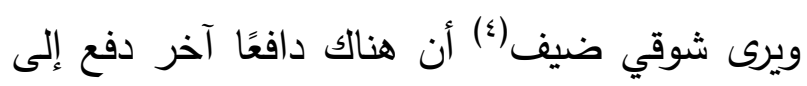
تقعيد اللغة والمحافظة عليها؛ ألا وهو اعتزاز العرب بلغتهم وخوفهم عليها من الأعاجم. ويرى آخرون(0) أن من الدوافع الدافع اللغوي، ويتمثل الاعاجن في تداخل اللغة العربية بغيرها من اللغات كالفارسية والسريانية.

وقد أدرك المشتغلون باللغة -منذ البداية- أن تعليم

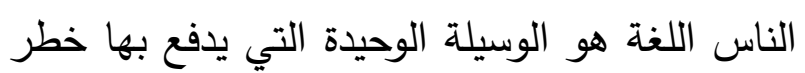
اللحن، فاتجهوا إلى ضبطها وتقعيدها من خلال

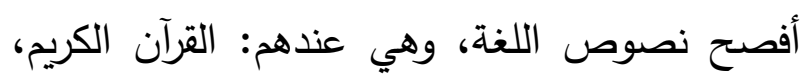
والحديث الثريف وكلام العرب الفصحاء (شعرًا ونثرًا). وكون القرآن الكريم المصدر الأول للسماع باعتباره

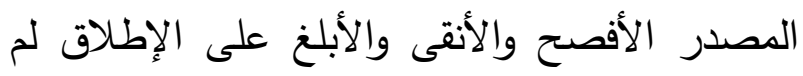

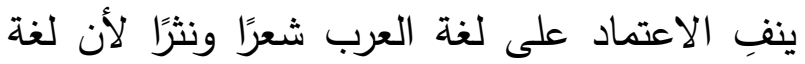
العرب هي بوابة فهم القرآن الكريم ولغته، قال تعالى:

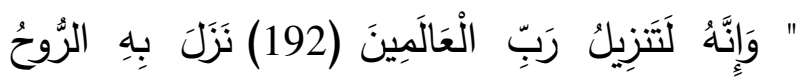

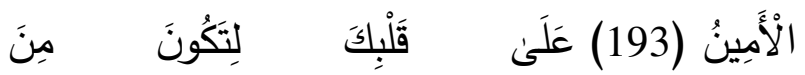

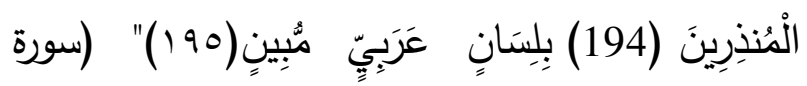
(") تاريخ الأدب العربي، كارل بروكلمان، نقله إلى العربية عبد الحليم

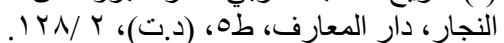

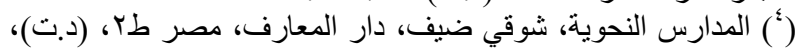
(") المفصل في تاريخ النحو، د. د. محمد خير الحلواني، مؤسسة الرسالة،

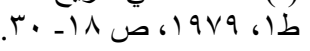

محمد - صلى الله عليه وسلم- وكلام العرب قبل بعثته وفي زمنه وبعده، إلى أن فسدت الألسن بكثرة المولدين نظمًا ونثرًا عن مسلم أو كافر "( (1). وهذا التعريف للسماع بأنه ما سمع من الكلام

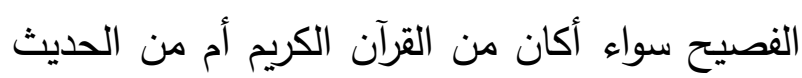
الشريف أم من كلام العرب الفصحاء شعرًا ونثرًا

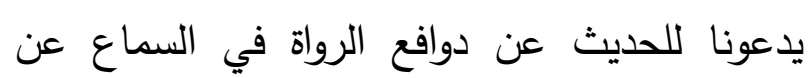
العرب وجمعهم للغة عنهم؛ لأن ذلك سيؤثر في المادة اللغوية المجموعة وبالتالي في التقعيد النحوي لاني -كما سيظهر في باقي البحث-.

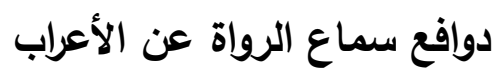

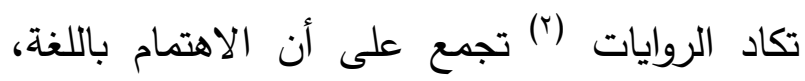

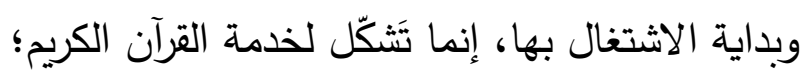
وذلك من خلال تفسير آيات القرآن الكريم، وبيان

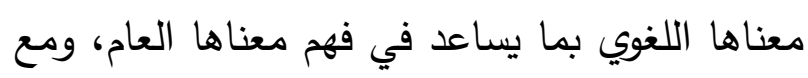
بداية الفتوحات الإسلامية ودخول الكثير من غير مناعي العرب إلى الإسلام، وظهور اللحن في اللغة عامة، ثم وصل إلى القرآن الكريم كان لابد من الحفاظ على الإنى النص القرآني من اللحن من خلال الحفاظ علية ووضع الضوابط اللغوية والقواعد التي تمنع اللحن من من الوصول للنص القرآني. (') الاقتراح في علم أصول النحو، جلال الدين السيوطي، تحقيق أحمد سليم الحمصي ومحمد أحمد قاسم ، جرس برس، بيروت، لون 1911،

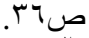

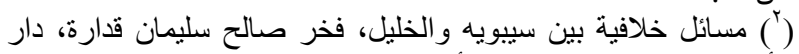

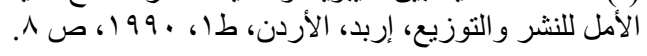




\section{حدود السماع}

لأهمية السماع ولمكانته الرئيسة في التقعيد النحوي وضع العلماء حدودًا لمن يؤخذ عنهم السماع تمثلت في الحدود الزمانية والحدود المكانية: أما الحدود الزمانية فتتمثل في الفترة التي ظلت فيها اللغة سليمة خالية من العيوب واللحن على ألسنة العرب، وقد اعتنى العلماء بتحديدها من العصر الجاهلي إلى نهايات القرن الرابع الهجري، كما جاء عن السيوطي " وكلام العرب قبل بعثته-صلى الله عليه وسلم- وفي زمنه، وبعده إلى أن فسدت الألسنة

بكثرة المولدين نظمًا أو نثرًا (0). ويظهر من كلام السيوطي أن الحدود الزمانية للسماع اللغوي تشتمل على العصر الجاهلي المحدد تقديرًا بمئتي سنة قبل الإسلام، ثم عصر صدر الإسلام كاملًا، وصولًا إلى الزمن الذي شاع فيه اللحن، وبدأ فيه الخطل يدب على ألسنة الأعراب، وكان ذلك في نهايات القرن الرابع الهجري، حيث ترك السماع عنهم ، ولم يأخذ أكثر العلماء بلغتهم، وفي هذا يقول ابن جني " وكذلك لو فثا في أهل الوبر ما شاع في لغة أهل المدر من اضطراب الألسنة وخبالها، وانتقاص مادة الفصاحة وانتشارها، لوجب رفض لغتها ، وترك تلقي ما يرد عنها، وعلى ذلك العمل في وقتتا هذا" (؟).

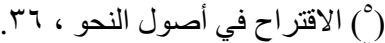

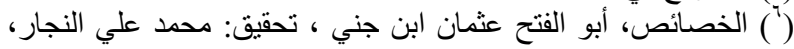

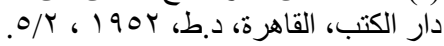

الشعراء) ، بدليل ما رواه القرطبي في تفسيره عن عمر بن الخطاب- رضي الله عنه- وقد سئل عن لفظ في القرآن، قال: أيها الناس عليكم بديوانكم لا يضل • قالوا : وما ديواننا ؟ قال : شعر الجاهلية فإن فيه تفسير كتابكم ('). وروى سعيد بن جبير(r) قال : " سمعنا عبد الله بن عباس يُسأل عن الثئ من القرآن فيقول فيه كذا وكذ، أما سمعتم الشاعر يقول كذا وكذا. وعن عكرمة(r) قال: ما سمعت ابن عباس فسر آية من كتاب الله إلا نزع فيها بيتًا من الشعر • ومن هذه الأقوال وغيرها يظهر جليًا كيف كانت اللغة عامة والشعر خاصة بوابة للقرآن الكريم ومفتاحًا لفهمه وتفسيره؛ ولذلك ازدادت الحاجة للسماع عن فصحاء العرب، والاحتجاج بكلامهم وصولاً إلى عصر التدوين والتأليف؛ إذ ظهر الاحتجاج بكلام العرب طاغيًا على الاحتجاج بلغة القرآن، فقد استشهد سيبويه- على سبيل المثالبألف وخمسين بيتًا من الشعر في كتابه مقابل بضعة

وثلاثمائة آية فقط (ء).
(') الجامع لأحكام القرآن، محمد بن أحمد الأنصاري القرطبي، دار عالم

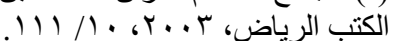

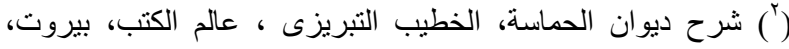
$r / 1$ 6 1997

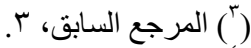

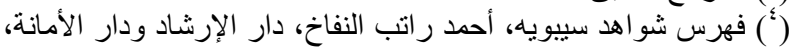

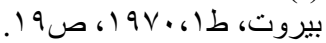


وهذه الحدود الزمانية والمكانية التي حددها النحاة لمصادر تقعيدهم سيظهر لنا فيما يلي تناقضهم في رفضهم بعض القراءات القرآنية المتواترة رغم أن صاحبها ممن تتطبق عليه الحدود الزمانية للسماع والأخذ عن العرب ناهيك أنه يقرأ نصًا مسموعًا

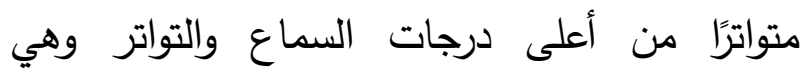
القراءات المتواترة!!!

وهذا يدعونا للنقطة التالية لنماذج تناقض النحاة بين كلامهم النظري في الاعتماد على القراءات القرآنية ورفضهم لبعضها عند التطبيق.

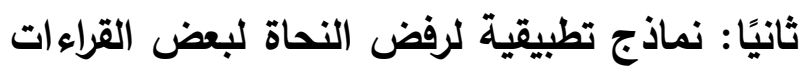
القرآنية، وتناقض ذلك مع موقفهم النظري بقبولها.

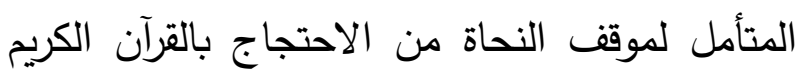
وقراءاته يلاحظ تناقضًا كبيرًا بين موقفهم النظري في لتراه

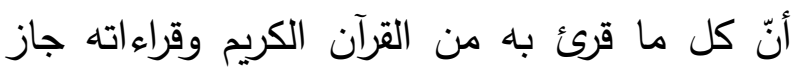

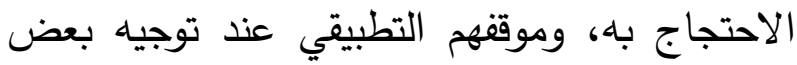
القراءات بردها أو غير ذلك من مواقفهم التي ستظهر معنا في السطور التالية. أما موقفهر النظري فعبر عنه بجلاء السيوطي بقوله:" أما القرآن فكل ما ورد أنه قرئ به به جاز الاحتجاجُ به في العربية، سواء أكان متواترًا، أم أم أران آحادًا، أم شاذًّا، وقد أطبق الناسُ على النى الاحتجاج بالقراءات الثاذة في العربية إذا لم تخالف قياسًا معلومًا، بل ولو خالفته يحتج بها في مثل ذلك بلك الحرف بعينه، وإن لم يجُزِ القياس عليه"(r)
وعلى ذلك فالحدود الزمانية لجواز السماع عن العرب، والاستشهاد بلغتهم تحدد بستمئة سنة، كحد أقصى، وهي الفترة الممتدة من مئتي سنة قبل الإسلام، حتى سنة (· .. هـ)، وليست كلها سماعًا مباشرًا ، إنما يدخل فيها الرواية عن العرب الفصحاء والأعراب ، والتي بدأها (1) أبو عمرو بن العلاء

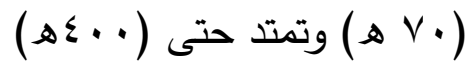
أما الحدود المكانية فيقصد به المكان الذي تمت فيه عملية السماع اللغوي، وهو محدد بفعل حركة

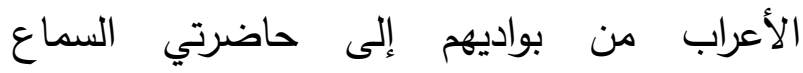
"البصرة"و"الكوفة" أو بفعل حركة رواة اللغة منهما (البصرة والكوفة) إلى بوادي العرب للسماع عنهم، والتي يمكن أن نجمل الحدود الدكانية في القبائل التي أخذت عنهم اللغة كما ذكر السيوطي: "والذين عنهم نقلت اللغة العربية ، وبهم اقتدى ، وعنهم أُخذ الخذ اللسان العربى، من بين قبائل العرب هم: قيس وتميم

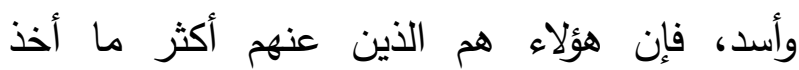
ومعظمه، وعليه اتكل في الغريب وفي الإعراب والتصريف، ثم هذيل وبعض كنانة وبعض الطائيين، ولم يؤخذ عن غيرهم من سائر قبائلهم"(r).

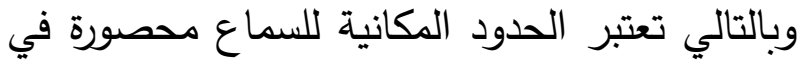
القبائل الستة: قيس وتميم وأسد وهذيل وبعض كنانة وبعض الطائيين،ولم عن غيرهم من قبائل العرب كما

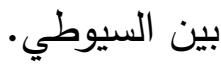
(') الاستشهاد والاحتجاج باللغة، محمد عيد، عالم الكث، القاهرة، طس،

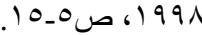
( ) الاقتر اح في علم أصول النحو، ع ؟. 
أما القراءة المتواترة فهي القراءة التي نقلها جمع لا يمكن تواطؤهم على الكذب عن مثلهم إلى منتهي سندها (ع). وأما القراءة المشهورة فهي القراءة التي صح سندها، ولم يبلغ درجة التواتر ، ووافقت رسم المصحف ولورة الوراءه احتمالًا ووافقت وجهًا من وجوه العربية، واشتهرت ورت

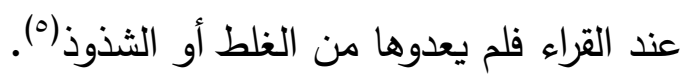

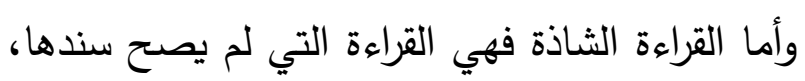
أو خالفت الرسم ، أو لا وجه لها في العربية(؟). قال شهاب الدين الدمياطي:" القراءات بالنسبة للتواتر وعدمه ثلاثة أقسام: قسم اتفق على تواتره وهم السبعة المشهورة وقسم اختلف فيه وهم الثلاثة بعدها، وقسم لتحم اتفق على شذوذه وهم الأربعة الباقية(Y). ويرى أبو عمرو الداني أن الأصل في القراءة هو لإنهاءه

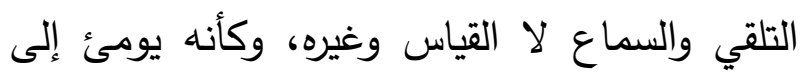

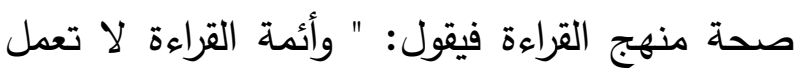
في شيء من حروف القرآن على الأفشى في اللغة،

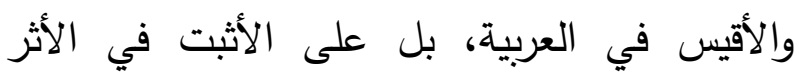

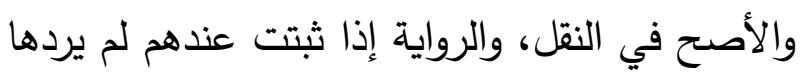
قياس عربية ولا فشو لغة، لأن القراءة سنة متبعة يلزم قبولها والمصير إليها (^).

(") الإتقان في علوم القرآن، جلال الدين السيوطي، الهيئة الدصرية العامة

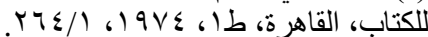

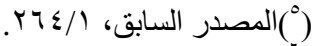

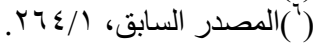

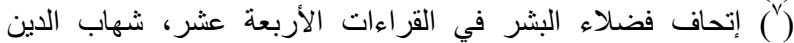

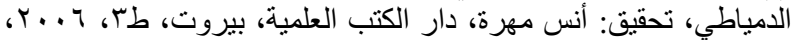

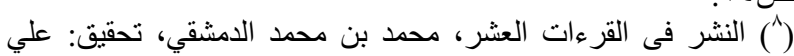

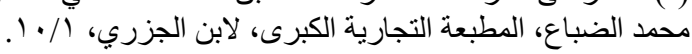

وكذلك نجد ابن جني قبله يدافع عن القراءات وحجيتها ليست المتواتراة فقط بل حتى الثاذة بقوله

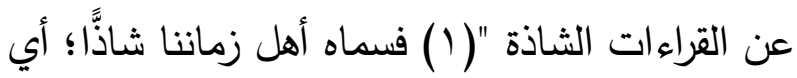

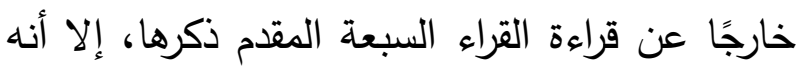

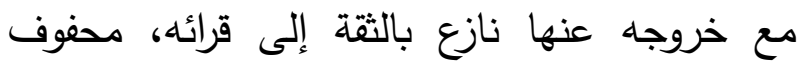

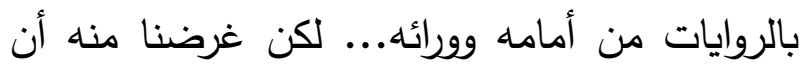

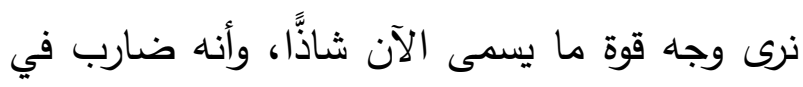

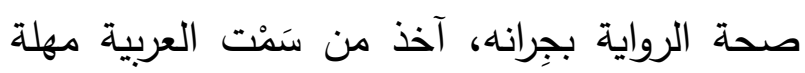

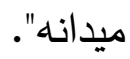

وكذلك نجد إمام مدرسة الكوفة(r)-ثعلب- يساوي وجوه الإعراب في قراءات السبعة ولايفضل وجهًا على وجه، وإذا خرج إلى كلام الناس أخذ بالوجه

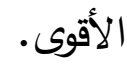

وكذلك نجد أبا حيان الأندلسي ينتصر للقراءات

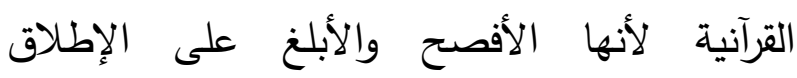
بقوله(r):" إن كلام الله أفصح كلام فينبغي حمله الأهل

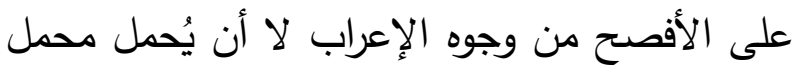
شعر امرئ القيس أو الأعشى". وآل الإعراب

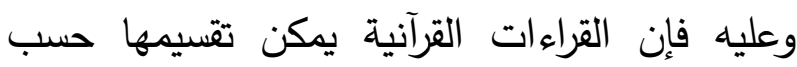
المتعارف عليه عند علماء القراءات إلى: القراءات المتواترة، والقراءات المشهورة، والقراءات الثاذة.

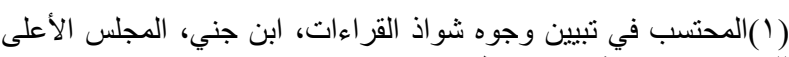

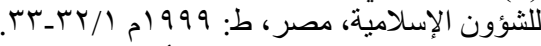

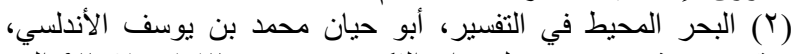

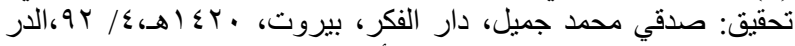

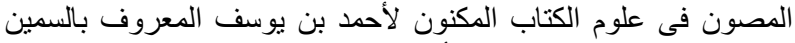

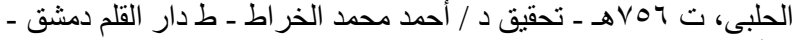

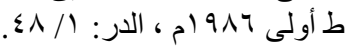

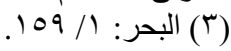


في تقريرها ببيت مجهول فرحوا به، وأنا شديد التعجب منهم إذا جعلوا ورود ذلك البيت المجهول على وفقها دليلاً على صحتتها ، ولأن يجعلوا ورود القرآن دليلاً على صحتها كان أولى (). ويبدي ابن حزم كذلك عجبه من ذلك فيقول :" ولا عجب أعجب ممن إن وجد لامرئ القيس أو لزهير أو لجرير أو الحطيئة أو الطرماح أو لأعرابي أسدي لهي لهي أو سلمي أو تميمي أو من سائر أبناء العرب لفظًا

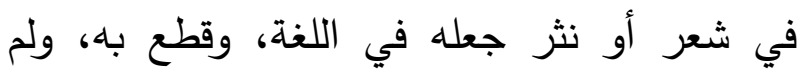
يعترض فيه، ثم إذا وجد لله تعالى خالق اللغات

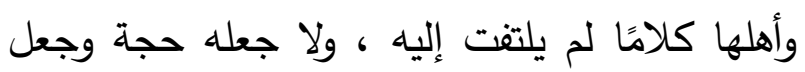
يصرفه عن وجها ويحرفه عن موضعه ويتحيل في إحالته عما أوقعه الله عليه (๕). وهذا هو الاتجاه الغالب على جمهور النحاة وخاصة الهُه

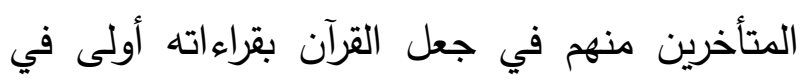
التقعيد النحوي من الشعر أو القياس أو العلة.

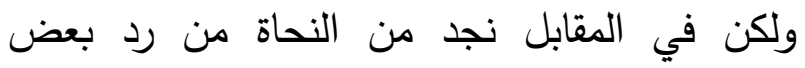
القراءات، ولم يقتصر في هذا الرد على القراءات

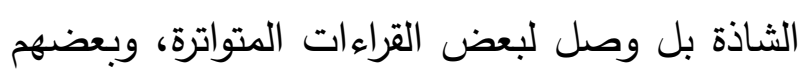
خطأها، فها هو المبرد يبالغ في رفضه لبهن لقراءة حمزة

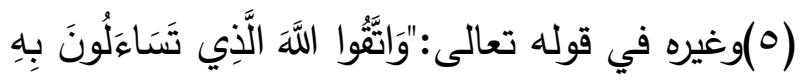

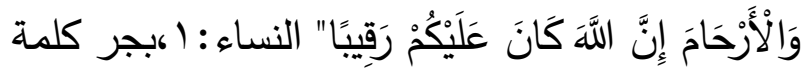

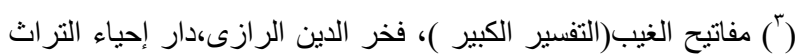

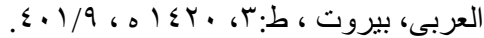

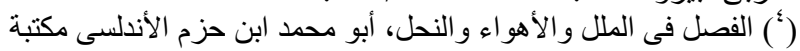

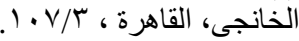

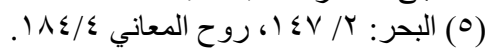

ويرى محمد عيد أن النحاة صرفوا أنفسهم قصدًا عن الاستشهاد بالقرآن والحديث مع علمهم بوجود هذه

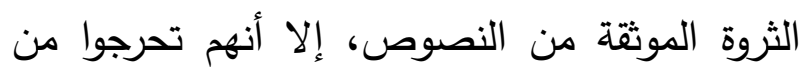

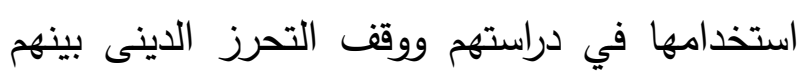
وبين الإفادة منها'(') ومن المحدثين(ז) من يرى أن علم القراءات القرآنآنية

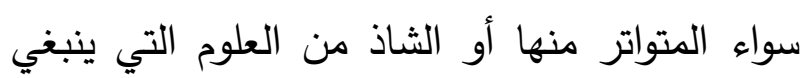

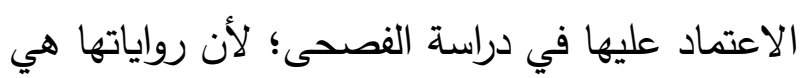

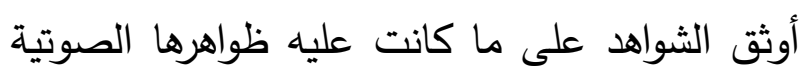

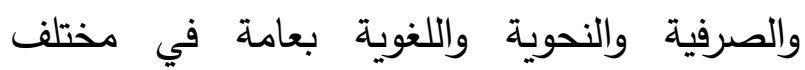
اللهجات، بل إن من الممكن القول بأن القراءات

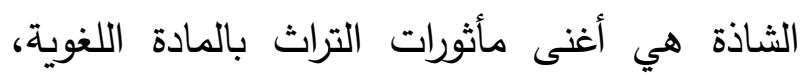
والتي تصلح أساسًا للدراسة الحديثة. ويظهر مماسبق اتجاه عدد كبير من العلماء إلى لى

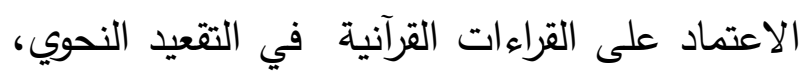
بل إعطاء الأولوية في الاستشهاد للقراءة القرآنية حتى لو وصفت بالثذوذ خصوصًا إذا كان النقل بها الهاء

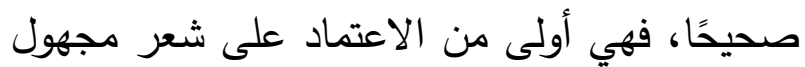

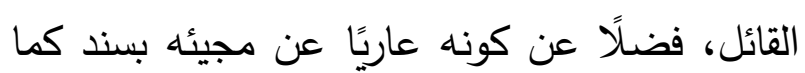
القرآن والحديث، وهذا ما جعل فخر الدين الرازى يعجب من تقديم الشعر على القراءات في التقعيد بقوله: "إذا جوزنا إثباتها بشعر مجهول، فجواز إثباتها

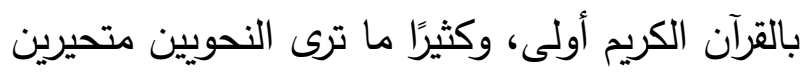
في تقرير الألفاظ الواردة في القرآن، فإذا استشهدوا

(') الرواية والاستشهاد، د. محمد عبيد، دار عالم الكتب، بيروت، طب،

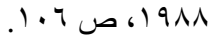

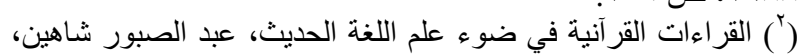


والغريب في هذا الاتجاه الرافض لبعض القراءات

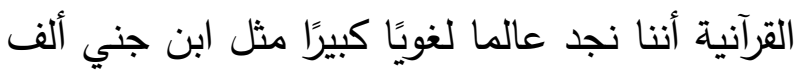
كتابه المحتسب للدفاع عن القراءات الثاذة وبيان وجهها اللغوي وحجيتها النحوية نجده يرفض قراءة متواترة هي قراءة ابن عامر السابقة ويقول عنها في الخصائص:"وهذا في النثر وحال السعة صعب هداعة الندا،

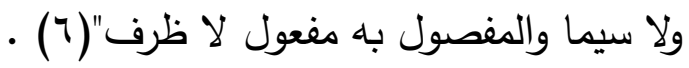
وتخريج موقف ابن جني هذا ربما يرجع للتطور الفكري لديه بين المرحلة التي كتب فيها الخصائص

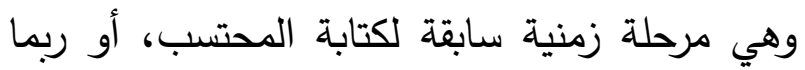
هذه الحالة بعينها تظهر مدى التناقض الذي وقع فيه النحاة بين أصولهم ومنطلقاتهم النظرية وتطبيقهر العملي.

ثالثًا: بعض القواعد التي اعتمد في تقعيدها على الثعر أو الأقيسة العقلية فقط، ولو اعتمد على اعلى القراءات القرآنية لزال الجدل والخلاف. كما قلنا سلفا إن الثعر وكلام العرب بوابة القرآن الكريم ومفتاحه؛ ولذا نقل السيوطي عن ابن عباس رضي الله عنهما- قوله :"الثعر ديوان العرب، فإذا خفي علينا الحرف من القرآن، الذي أنزله الله بلغة

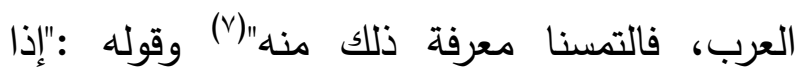
سألتموني عن غريب القرآن فالتمسوه في الثعر ، فإن الشعر ديوان العرب"(^)، وقد لقيَ الثّعر عناية كبيرة

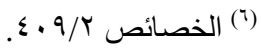

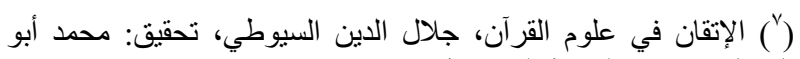

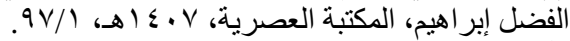

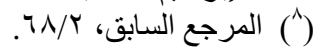

"والأرحامِ" فيما حُكي عنه( (1):"الو صليت خلف إمام

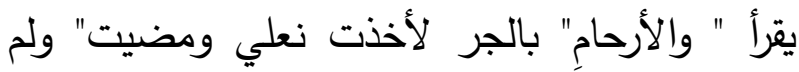
أقف على هذه الجملة في كتبه ،ولكنه رفض القراءة في الكامل بقوله"وهذا لا يجوز عندنا"(ب)

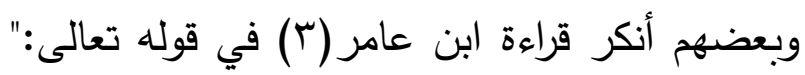

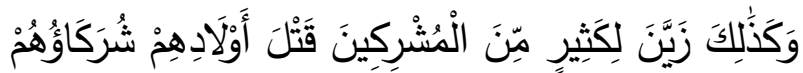

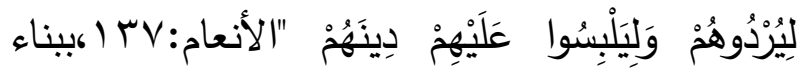
الفعل "زُين " للمجهول ورفع "قتلُ" على أنها نائب فاعل وبنصب "أولادَهم" وجر "شركائهِم" لأنه فصل بين المضاف"قتل" والمضاف إليه"شركائهر" بالمفعول "أولادهم" لدرجة أن الزمخشري وهو المفسر البليغ

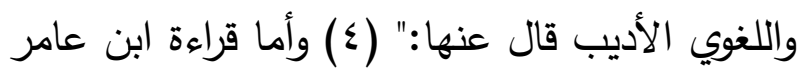
فشيء لو كان في مكان الضرورات وهو الشعر لكان

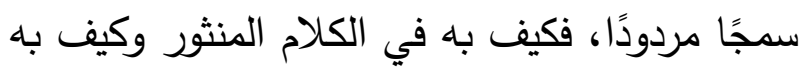
في القرآن الكريم المعجز بحسن نظمه وجزالته". وهذه النماذج على سبيل المثال لا الحصر؛ لنبين الاتجاه الموجود للى بعض النحاة في رفض بعض لهض

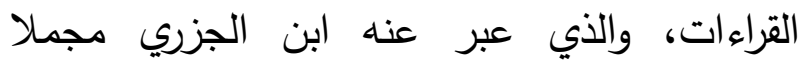

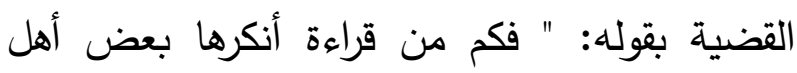

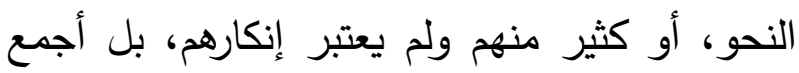

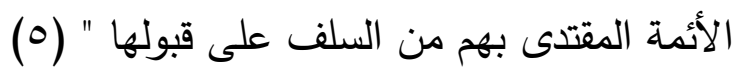
(1) (1رة الغواص فى أوهام الخواص للقاسم بن على الحريرى ـ تحقيق

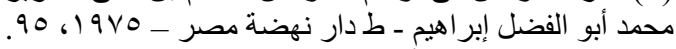

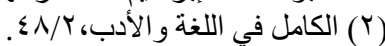

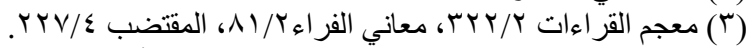

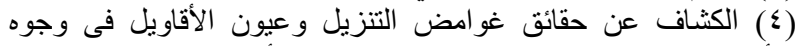

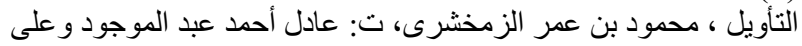

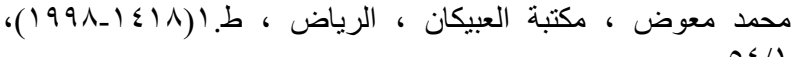

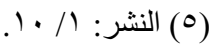




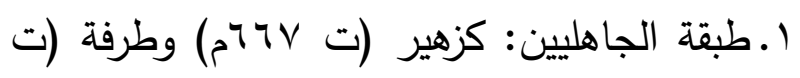

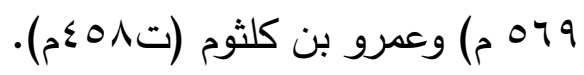
r.طبقة المخضرمين وهم الذين شهدوا الجاهلية

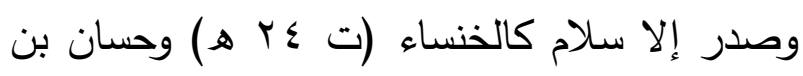
ثابت ( ع 0 هـ) وكعب بن زهير (ت ع ب هـ).

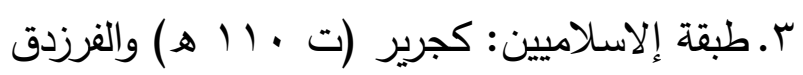

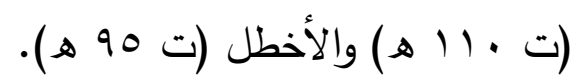
ع.طبقة المولدين أو المحدثين: وهم يبدعون في

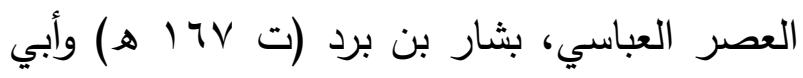
نواس (ت 199 هـ) وغيرهما. وقد أجمع علماء اللغة على أن شعراء الطبقتين

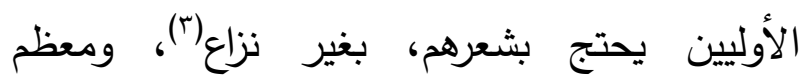
اللغويين يرون صحة الأخذ بشعر الطبقة الثالثة، بغير

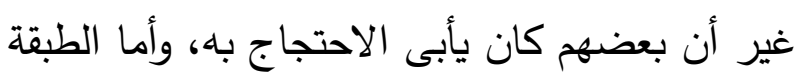

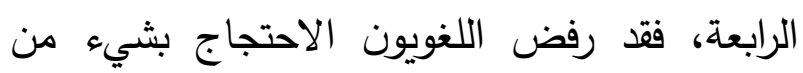
شعرها()،فيما عدا الزمخشري الذي أجاز ذلك(ه).

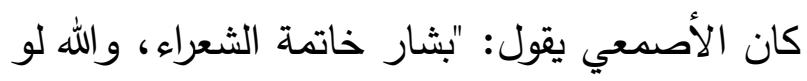

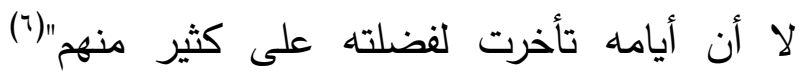
وواضح من ذلك أن مقصوده هو التوثيق اللغوي، إذ إذ إنى

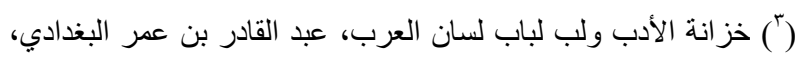

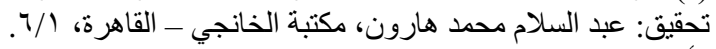

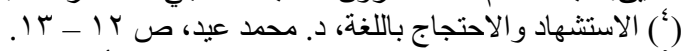

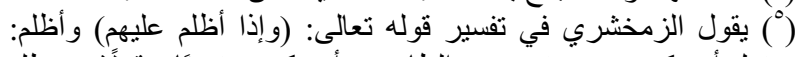

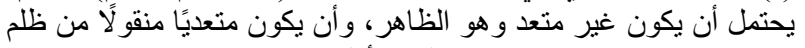

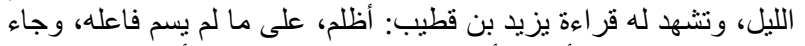

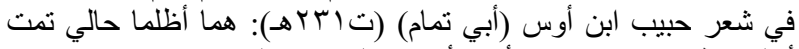

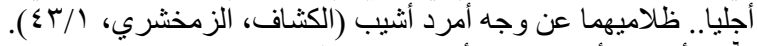

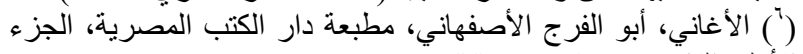

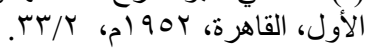

من طرف اللغويين حيث اعتبروه الدّعامة الأولى

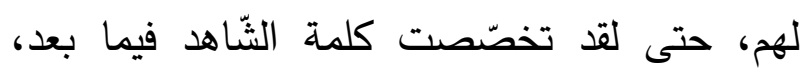

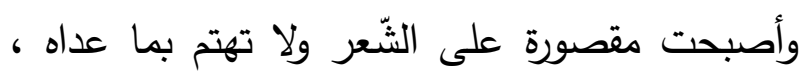
وقد كان اللغويون يستشهدون بالشعر المجهول قائله إن صدر عن ثقة يعتمد عليه('). لذلك نجد الثواهد الشعرية تملأ الكتب النحوية بل عند وتفوق الشواهد القرآنية في الاستشهاد بها ودرجة

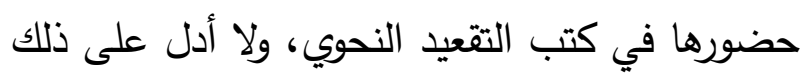
من النظر في كتابين مهمين في تاريخ النحو؛ وهو كتاب سيبويه والمقتضب للمبرد، فنجد الثواهد

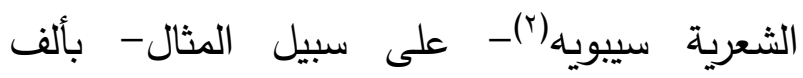
وخمسين بينًا من الثعر في كتابه مقابل أربعمائة وثلاث عشرة آية، على تقدير لاى العلماء ، ونجد

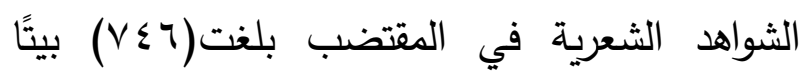

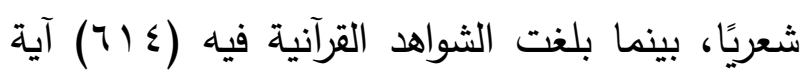
تقريبًا . تقديا، وهذا التواجد الكبير للشعر في كتب التقعيد النحوي رغم أنهم قيدوا الاستشهاد بالشعر بقيود كثيرة وحددوا

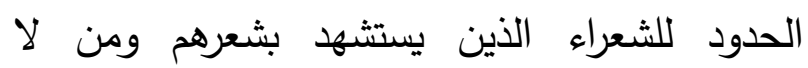
يستشهد بشعره كما ظهر في تناولنا للحدود الزمانية والمكانية للتقعيد النحوي، التي ليمكن إيجازها

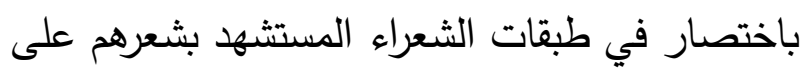

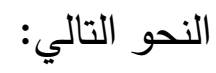

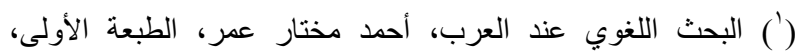

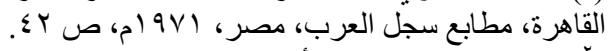

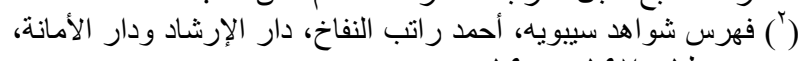

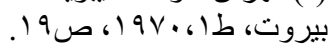


فإذا عطفت عليه كأنك عطفت الاسم على حرف الجر،وغيرها من الحجج العقلية التي لا تقف أمام المأثور المسموع وخاصة النص القرآني، ومنه قراءة حمة"تساءلون به والأرحام" وأيضا قوله تعالى (وكفر

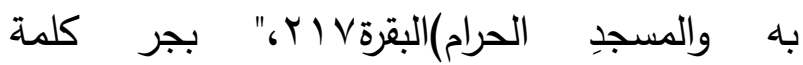
"المسجد"بالعطف على الهاء في "به"لا بالعطف على "سبيل" ،لاستلزامه العطف على المصدر قبل تمام صلته(乏)"، بل إن الشواهد الشعرية (0)كثيرة على

جواز هذا العطف ومنها قول الثاعر : (7) فاليوم قربت تهجونا وتشتمنا فاذهب فما بك والأيامٍ من عجب وبهذا يظهر جليا لنا أن الاعتماد على النص القرآني يخلصنا من مسألة خلافية من أكبر المسائل الخلافية التي شغلت النحاة قديما وحديثا، وملأت كتب النحو بين مؤيد ومعارض، ويرجعنا إلى مبدأ مهم من مبادئ التقعيد النحوي ألا وهو السماع أولى من غيره في الحجية والاستدلال، فما بالنا إذا كان المسموع هو النص القرآني. ثانيًا: مسألة (V)عدم جواز الفصل بين المتضايفين إلا في الشعر اضطرارًا، حيث ذهب كثير من النحاة إلى عدم جواز الفصل بين المضاف والمضاف إليه إلا في الشعر ، وبعضهم أجاز الفصل بينهما بالظرف

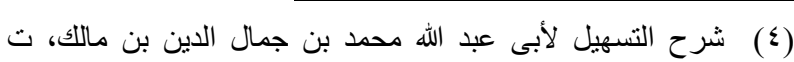

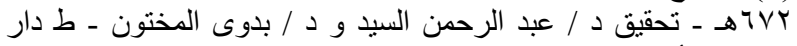

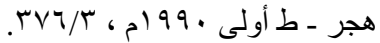

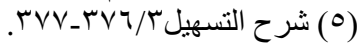

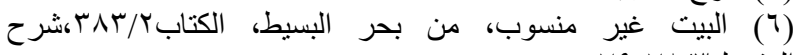

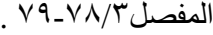

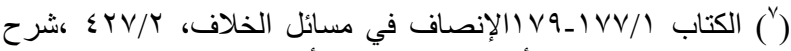

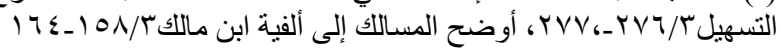

لا تحمل هذه الألفاظ على منطوقها من حيث "ختام الشعراء أو الطبع في الشعر أو ساقة الشعراء"('). وإن لم يكن الشاهد الشعري من عصر الاحتجاج دعي الثاهد مثالًا للاستئناس لا للبرهنة كشعر المتبي والمعري وغيرهما. وابن قتيبة يقول: "كان جرير والفرزدق والأخطل وأمثالهم، يعدون محدثين وكان أبو عمرو بن العلاء يقول: لقد كثر هذا المحدث وحسن، حتى لقد همدت بروايته(r). وهذا التواجد الكبير للشواهد الشعرية في التقعيد النحوي مع ضبط قواعد قبولها والاحتجاج بها وحد الحدود للمقبول منها من عدمه شيء إيجابي وأفاد النحو واللغة فائدة كبيرة إلا أنه من جانب آخر أضر النحو لأن بناء القواعد على الشواهد الشعرية فقط ضيق القواعد النحوية وأغلق جانبًا واسعًا من سعة اللغة العربية؛ لأن الثعر لله لغته الخاصة وقوانينه الخاصة من وزن وقافية ،فالاعتماد على الثعر فقط في التقعييد النحوي ضيق اللغة،وترتب عليه خلاف كبير وجدال لا حدود لله بين النحاة في الانتصار للقاعدة أم للنصوص المتعارضة مع ظاهر القاعدة كما سيظهر في المسائل التالية: أولاً: مسألة (r)عدم جواز عطف الاسم الظاهر على الضمير المجرور إلا إعادة حرف الجر محتجين بحجج منطقية كثيرة موجودة في المصادر وكلها تدور حول أن الجار والمجرور كثيء واحد

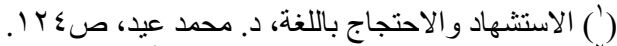

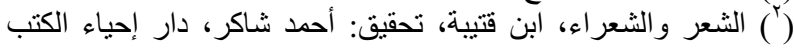

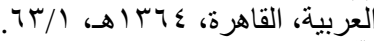

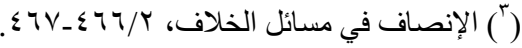


الأدلة التي ذكرها العلماء(؛) التي توجب علينا أن ننهي الخلاف على هذه القضية التي تعد القضية الأكبر إشغالًا للنحاة قديمًا وحديثًا ،وأخذت حيزا كبيرا

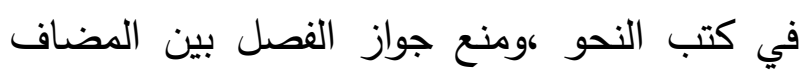

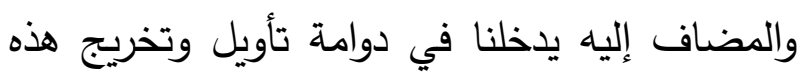
النماذج الكثيرة ،وأما إجازة الفصل يجنبنا الجدال والخلاف ويفتح المجال أمام هذه النماذج لإضافة رحابة للغة العربية وقواعدها ،خاصة وأن أقوى الأدلة على جوازها قراءة ابن عامر ،وهي قراءة متواترة

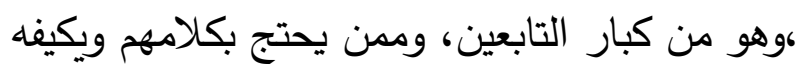

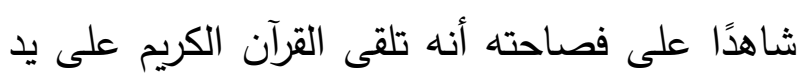
سيدنا عثمان بن عفان رضي الله عنه ،كما قال البنا الادمياطي(0) ثالثًا: إعمال (إنْ) المخففة من الثقيلة حيث اتفق

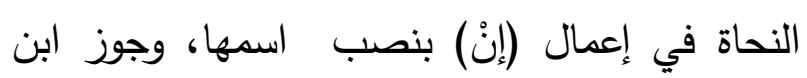
هشام الإعمال والإهمال ورجح الإهمال(T) ولكنهم

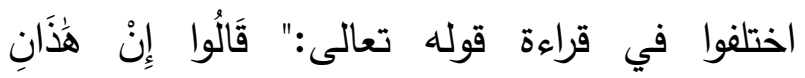

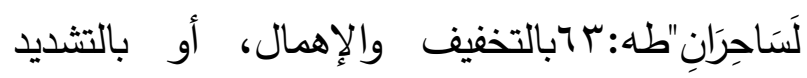

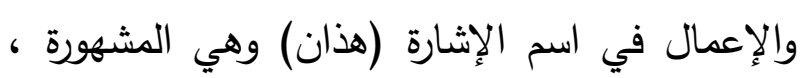
فمن أعملها مع التشديد نصب اسم الإشارة محلا واعتبره مبني لأنه ألزم المثنى طريقة واحدة في جميع حالات الإعراب واعتبرها لغة مشهورة بين قبائل الغئل العرب كخثعم وبني الحارث بن كعب ، ومن أهملها

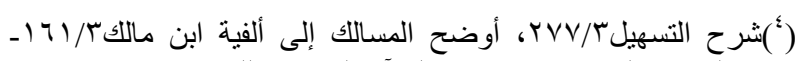

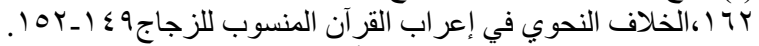

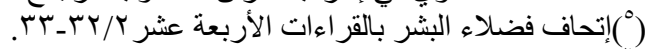

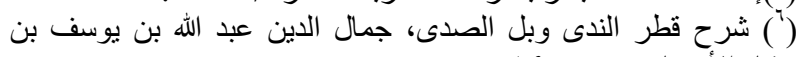

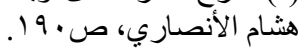

والجار والمجرور؛ لأنهما يجوز فيهما التوسع ما لا

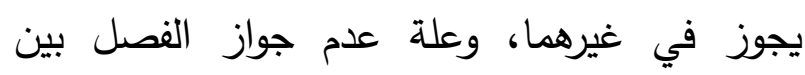

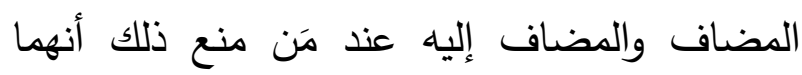

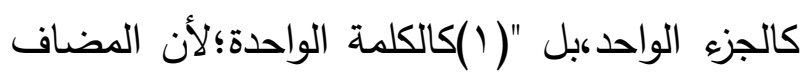

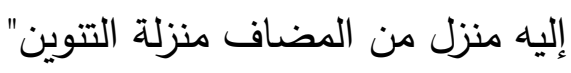

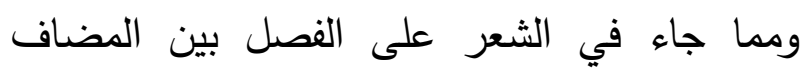
والمضاف إليه بالظرف وحملوه على الضرورة قول عمرو بن قميئة: لما رأت سَاتِيدما اسنَعَبرتْ لله دَرُّ اليومَ مَنْ لامها

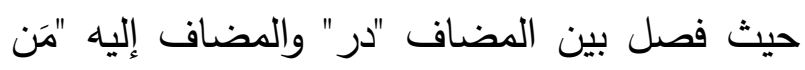
لامها" بالظرف "اليوم".

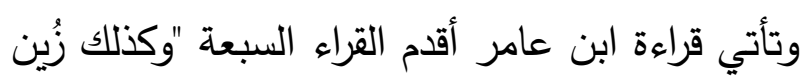
لكثير من المشركين قتلُ أولادهم شركائهم" بالفصل

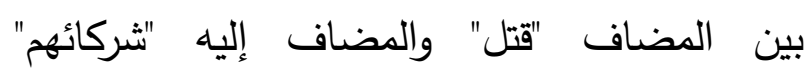
بمعمول المضاف- المفعول-" أولادهم" أكبر دليل على جواز الفصل بين المضاف والمضاف إليه لوروده في قراءة متواترة معتبرة وقارئها من أقدم القراء

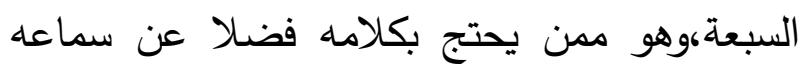

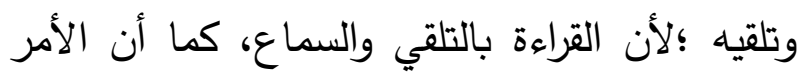
ليس مقتصرا على قراءة ابن عامر إنما توجد شواهد

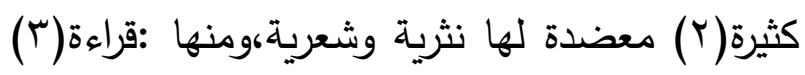

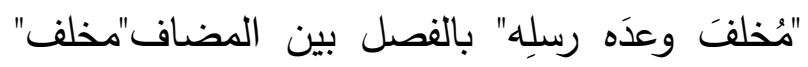

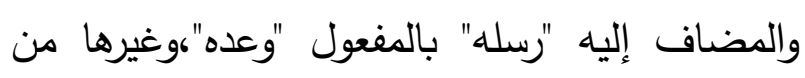

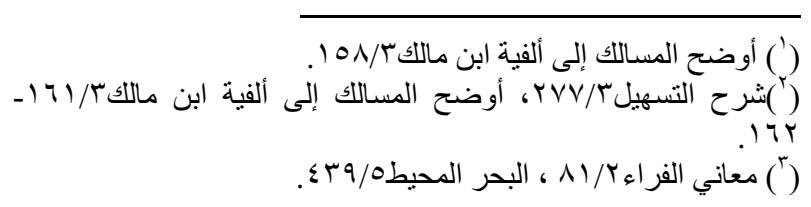


ومحل الشاهد (بين أذناه)، والقياس أن يقول (بين أذنيه) للإضافة، ولكنه ألزم المثنى طريقة واحدة حتى في حال الإضافة لأنها لغة عندهم.

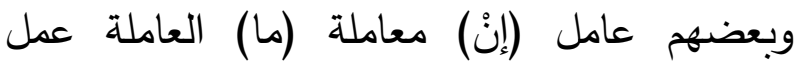

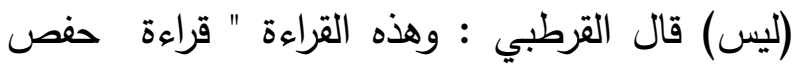
وابن كثير" سلمت من مخالفة المصحف وفساد

الإعراب ويكون معناها "ما هذان إلا ساحران" (ع) ومع هذا الاختلاف في القراءة اختلف النحاة في التقدير وعدمه في الإعراب ، والبحث للقراءة المخالفة

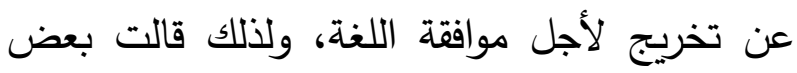
المدارس بجواز أن تكون (إن) مخفقة وتعمل ، وقال بعضهم تعمل عمل (ليس) ومن هنا يظهر تأثير

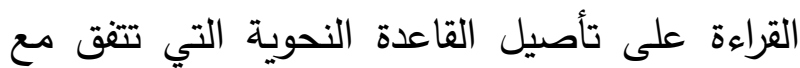
لغة العرب ولهجاتهم الواردة عن بعضهم ؛ولذلك القول بالجواز عمل "إنْ" المخففة من الثثيلة يعطي القاعدة النحوية رحابة وسعة في احتواء النماذج

$$
\text { المسموعة عن العرب. }
$$

رابعًا:جواز نصب الفعل المضارع بعد الفاء في جواب "لعل" أو رفعه حيث منع البصريون نصب لهب الفعل المضارع في جواب "لعل" وأما الكوفيون فقد أجازوا نصبه بعد الفاء في جواب "لعل"(0) واستدلوا على جوازه بقوله تعالى :" وَقَالَ فِرْعَوْنُ يَا هَامَانُ ابْنِ

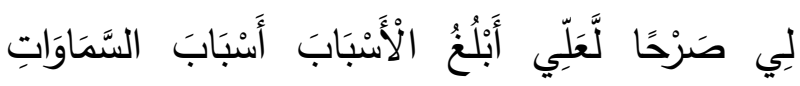

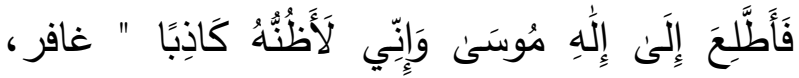
צr
أعرب اسم الإشارة رفعًا بالألف لأنه مثنى ونصبًا وجرًا بالياء وهي ما جاء بها المصحف والرسم القرآني. وإلزام اسم الإشارة ألف المثنى في حالات الإعراب الثلاثة هي لهجة بني الحارث بن كعب وخثعم الإنسار

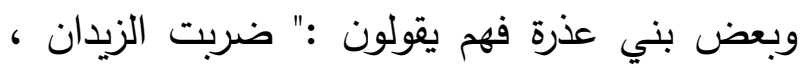
ومررت بالزيدان، كما تقول :جاءني الزيدان ونسبها الزجاج إلى كنانة، وابن جني إلى بعض بني ربيعة ،

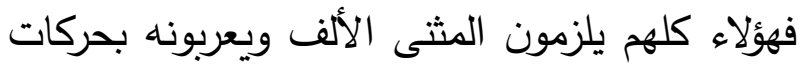

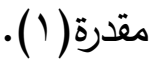
وقد قرأ ابن كثير "إنْ هذان" بتخفيف "إنْ" وتشديد

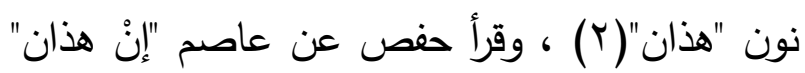
بتخفيف النونين، وعن الأخفش إنها خفيفة في معنى الثقيلة وهي لغة قوم يرفعون بها، ويدخلون اللام ليفرقوا بينها وبين التي تكون في معنى "ما" التي لتحني تعمل عمل ليس. وعلى ذلك فهي لغة مشهورة عند بعض القبائل ، وقد نزل بها القرآن الكريم واستشهد بها شعراؤهم كقول

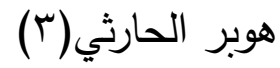

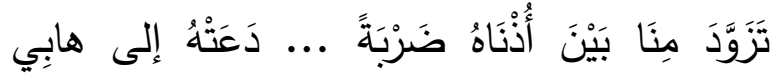
التُّرَابِ عَقِيم

(') منحة الجليل بتحقيق شرح ابن عقيل ، فى هامش شرح ابن عقيل،

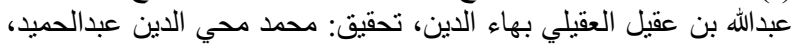

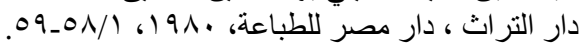

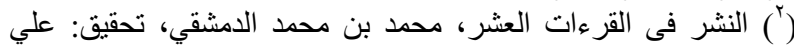

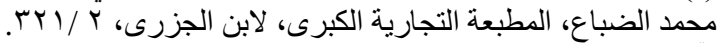

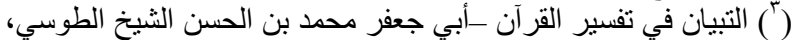

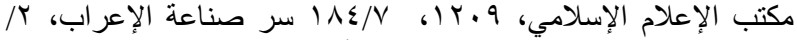

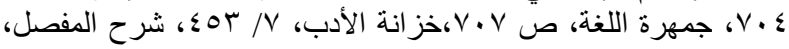


لََظَنُُْهُ كَاذِبًا" في قراءة بعض السبعة بنصب (أطلع)

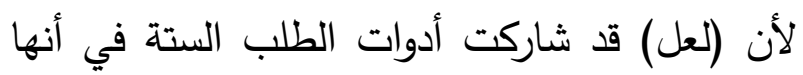
لغير الإيجاب، ثم إن قراءة النصب أبلغ من غيرها

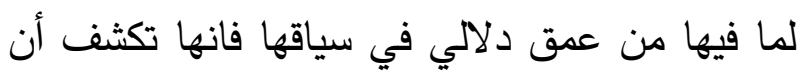

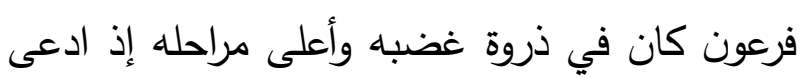
الألوهية ونفي أن يكون هنالك إله غيره ، فقال:" وَقَّالَ

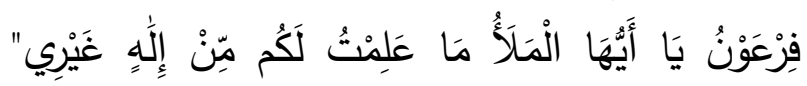
القصص: ریז، فكان هذا كدعاة للتكبر والتبجح فيرتجى من الصرح الذي طلب من هامان بناءه أن يطلع به إلى موسى وبهذا ناسب كل لفظة في رواية

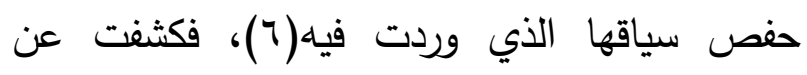

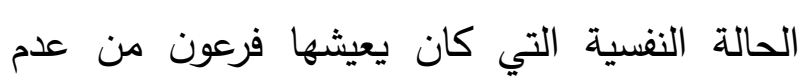

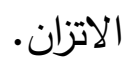

ولكل من القراءتين دلالة معنوية تختلف عن الأخرى

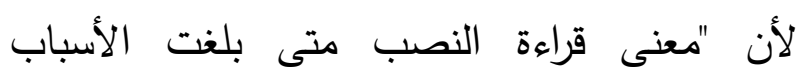

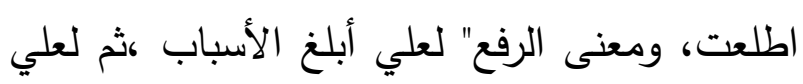

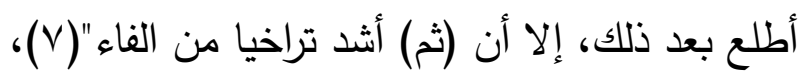

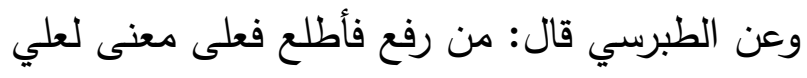

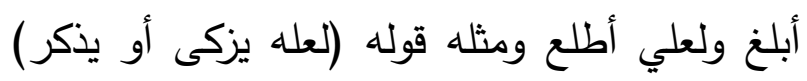
وليس بجواب، ومَن نصب جعله جوابًا بالفاء لكلام

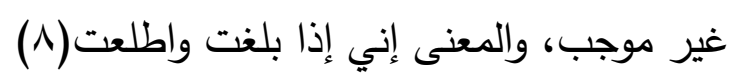

(") القيمة الدلالية للتر اكيب النحوية في قراءة حفص عن عاصم للاكتور

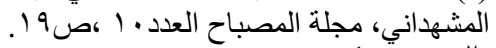

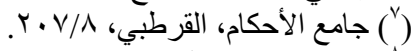

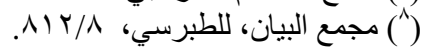

والنصب، فقد قرأ حفص عن عاصم بالنصب بخلاف باقي القراء السبعة الذين قرؤوها بالرفع ( (1).

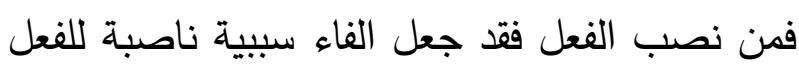
في جواب الترجي ومن رفعه عطفة على ما قبله(ب)

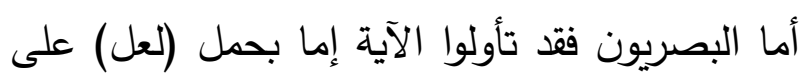
التمني بمعنى (ليت) أو بعطف الفعل على معنى

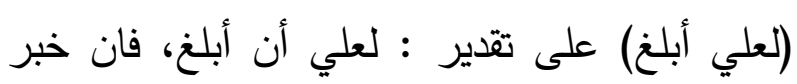
(لعل) يقترن ب(أن) كثيرًا (r). وأما الكوفيون فقد أجازوا نصبه بعد بعدان الفاء في جواب (لعل)(ع) واستدلوا على جوازه بهذه القراءة وبقول

الثاعر : (0) علّ صروف الدهر أو دولاتها تدلنتا اللّمّة من لمّاتها فيكفي شاهدًا على صحة هذه القاعدة النحوية الآية

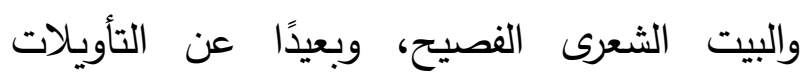
والتعليلات، ما دام الثاهد الفصيح قد ورد بها؛ ولهذا عدها ابن هشام قاعدة يقاس عليها، وقد ذكرها في تعداده لمواضع نصب الفعل المضارع بها بعد فاء

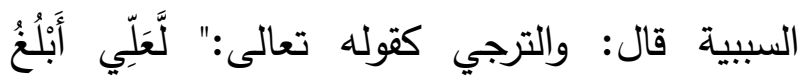

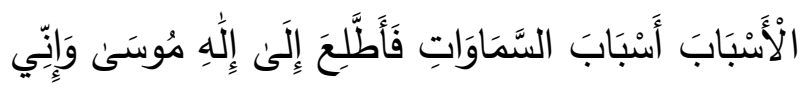

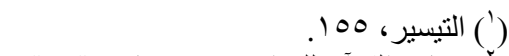

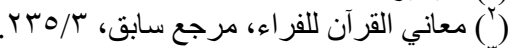

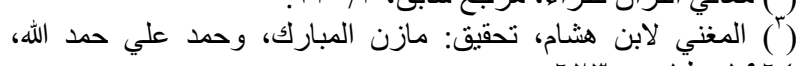

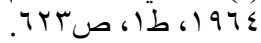

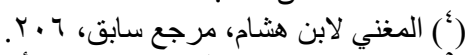

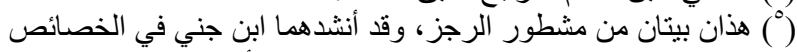

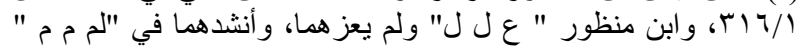

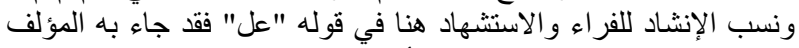

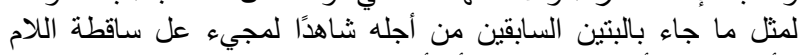

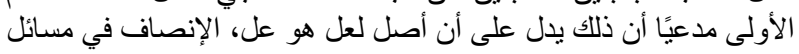

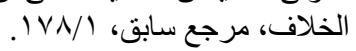


فهذا التوجيه لم يكن مقصورًا على القراءات العشر، بل تعداه إلى القراءات الثاذة لما فيها من ملامحَ نحويةٍ ولغويةٍ عديدةٍ ، وأحيانًا يكون هنالك توجيه للنوعين معًا في كتاب واحد، فهذه ثلاثة مناهج تأليفية في توجيه القراءات ، فمن النهج الأول :

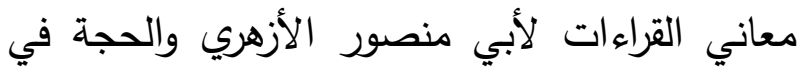

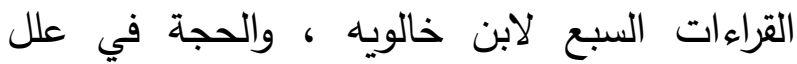
القراءات السبع لأبي علي الفارسي ، وحجة القراءات

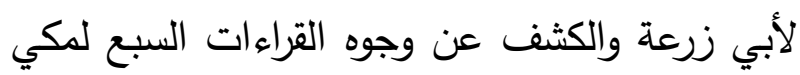

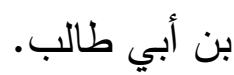
ومن النهج الثاني وهو توجيه القراءات الثاذة: المحتسب لابن جني، وإعراب القراءات الثواذ لأبي

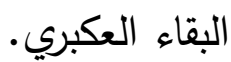

ومن النهج الثالث وهو الجمع بين توجيه القراءات

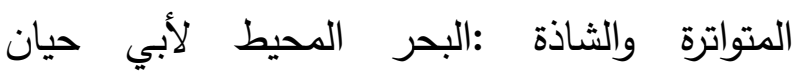
الأندلسي، والدر المصون في علوم الكتاب المكنون للسمين الحلبي، واللباب في علوم الكتاب لابن عادل الامشقي، ويبدأ كل مصنف من هذه المصنفات بذكر صاحب القراءة وضبط قراءته، ثم يشرع في توجيهها حسب قوانين الصناعة ، ويعربها ويشرح معناها،

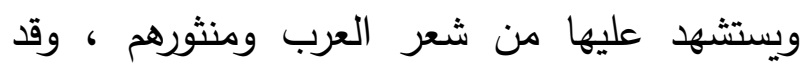

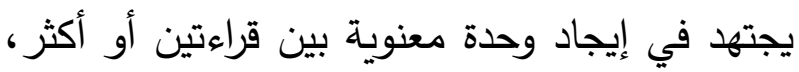
وقد لا يكون ثمة وحدة فيسعى المؤلف في التوجيه الذي يراه في ضوه علوم العربية المختلفة ، مِنْ لغةٍ لهِ ونحو وصرف وبلاغة
المحور الثاني

مظاهر اهتمام النحاة بالقراءات القرآنية:

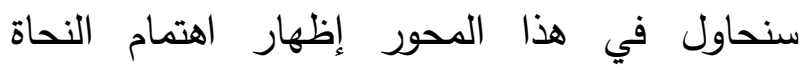
بالقراءات القرآنية، وتقديرهم لدورها في التقعيد النحوي من خلال عرض موحز جدًا بقصد التذليل على لئ

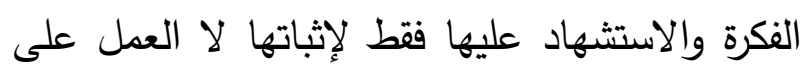
استقصائها؛ لأن الاستقصاء يخرج البحث عن هدفه

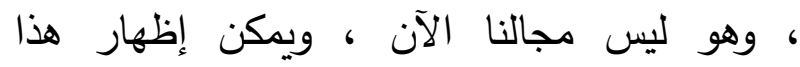
الاهتمام في عدة أمور من أهمها:

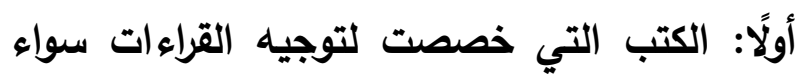
المتواترة أو الثاذة، وكتب معاني القرآن وإعرابه.

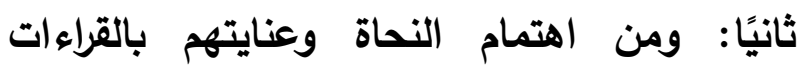
القرآنية أنهم استثهدوا بها في مواطن الخلاف

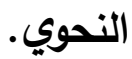
وهو ما سيظهر في السطور التالية. أولًا: أما الكتب التي خصني فيت لتوجيه القراءات سواء المتواترة أو الثاذة، وكتب معاني القرآن وإعرابه فقد عمل النحاة على بيان ما في القراءات من وجوه إعرابية ودراسة تلك الوجوه وتحليلها

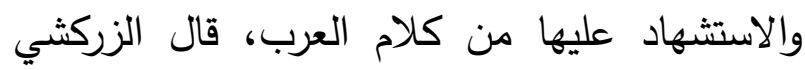

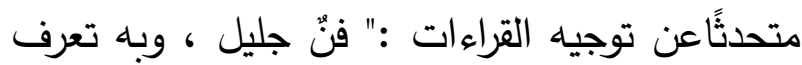

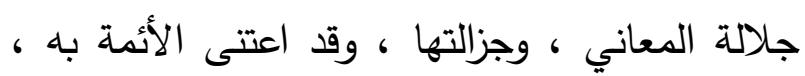

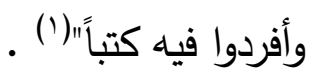

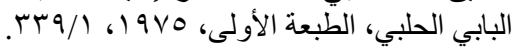


النهاية كلا الفريقين جنح إلى الاستشهاد بالقراءات

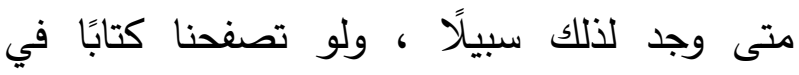
الخلاف النحوي ككتاب "الإنصاف في مسائل الخلاف" لوجدنا أنه تضمن عدة قراءات سيقت لأجل الاستشهاد بها على الفريق المخالف، فمثلًا في جواز

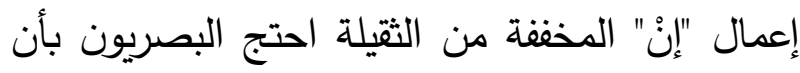
قالوا: الدليل على صحة الإعمال قوله تعالى: (إنَّ

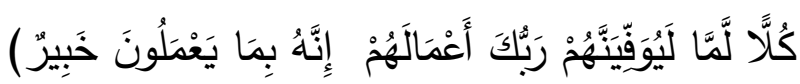
هود : 1111. في قراءة من قرأ بالتخفيف وهي قراءة نافع وابن كثير (r). وفي جواز العطف على الضمير المجرور "ذهب الكوفيون إلى أنه يجوز العطف على الضمير المخفوض، وذلك نحو قولك: مررت بك وزيدِّ، وذهب يجل البصريون إلى أنه لا يجوز، أما الكوفيون فاحتجوا بأن قالوا الدليل على أنه يجوز أنه قد جاء ذلان الك في التتزيل وكلام العرب، قال الله تعالى (يَا أَيَهَّا النَّاسُ

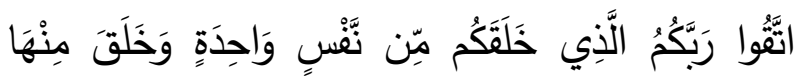

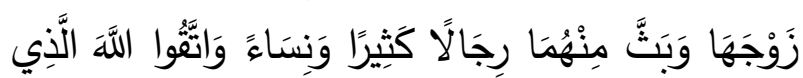

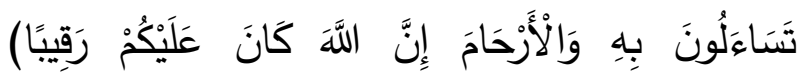
النساء: ابالخفض في كلمة "الأرحام" وهي قراءة أحد القراء السبعة وهو حمزة الزيات(ب). كذلك ذهب الكوفيون إلى جواز إدخال نون التوكيد الخفيفة على فعل الاثثين ومعهم يونس بن حبيب البصري، ومما استدلوا به قراءة ابن عامر : (قَالَ قَّْ
وقد حاول موجهو القراءات قدر إمكانهم استقصاء وجوه الإعراب في تلك القراءات حتى وإن كان وجهًا غريبًا؛ فها هو السمين الحلبي يقول في مقدمة كتابه:

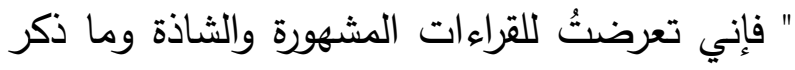
الناس في توجيهها ولم أترك وجهًا غريبًا من الإعراب

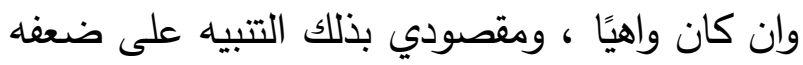
حتى لا يغتر به من اطلع عليه ... وهذا التصنيف

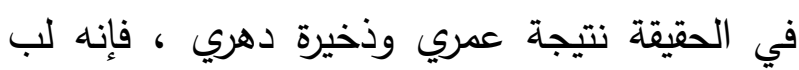
كلام أهل هذه العلوم ('). من هنا نخلص إلى أن النحويين أوْلَوا القراءات عنايتهم، فألفوا فيها كتبًا ضخمة، وتتبعوها قراءة إنيا قراءة، ووجهوا كل قراءة، وحشدوا الثواهد في توجيهها، وتلك عناية فريدة امتازوا بها عن غيرهم من أصحاب العلوم الأخرى، وهذا من أوثث العلائق

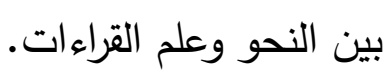

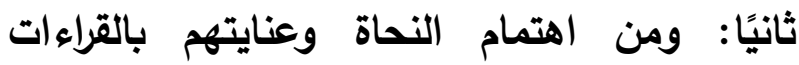
القرآنية أنهم استثهدوا بها في مواطن الخلاف النحوي، فعندما يحتدم الخلاف النحوي كما هو الحال بين البصريين والكوفيين نجد أن الاستشهاد بالقراءة القرآنية قائم على أشُدّه ، وحاضر فين في كل مساجلات الخلاف، وذلك يظهر جليًا في مسائل الخلاف بين البصريين والكوفيين ؛ إذ كل فريق في

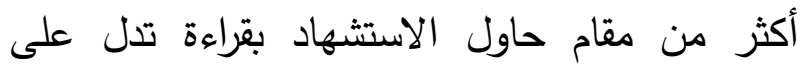
صحة مذهبه واستقامة منهجه ، وربما كان الكوفيون

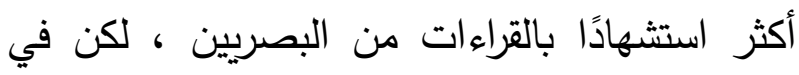


ومبتدأ لله فاعل سد مسد الخبر بشرط اعتماده على نفي أو استفهام، ولكنا نجد علماء القراءات يقولون: "مرفوع بالابتداء" ، وأحيانا "مرفوع على أنه مبتدأ"، كما جاء عن أبي السعود العمادي في تفسير قوله

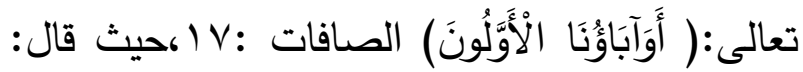
" رفع على الابتداء، وخبره محذوف عند سيبويه، أي: أو آباؤنا الأولون أيضا مبعوثون" (ب).

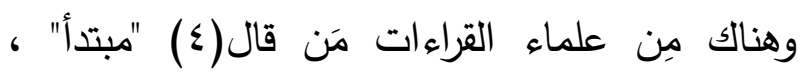
والفرق بين المصطلحين "الابتداء" و "المبتدأ" هو أن الابتداء يعني"(0)جعلك الاسم أو ما فى تقديره مُعرى من العوامل اللفظية غير الزائدة لتخبر عنه، أما المبتدأ فهو الاسم أو ما يأتي في تقديره ". r- مصطلح "نائب الفاعل" لقد تحدث كثير من النحاة عن هذا المصطلح، ولقد اختلفوا في تسميته، حيث قال الرضي :" فعل ما لم يسم فاعله، أي فعل المفعول الذي لم يسم فاعله، وإنما أضيف إلى المفعول ، لأنه بُني له" ، وقال ابن الحاجب :"فعل ما لم يُسم فاعله: هو ما حذف لئ

فاعله"(7). (7).

وقال المبرد :"المفعول الذي لا يذكر فاعله" (V)

r شرح قطر الندى وبل الصدى ، جمال الدين بن هشام الانصارى ، دار

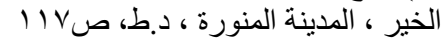

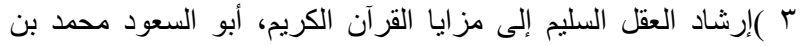

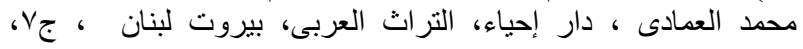
صن

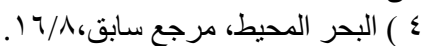

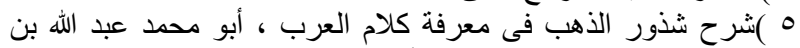

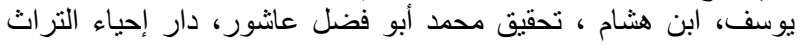

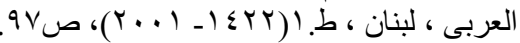

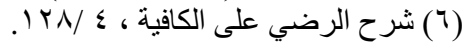

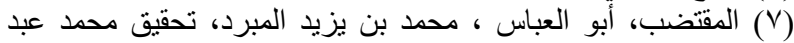

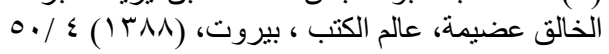

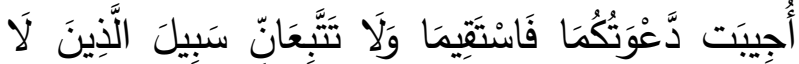
يَعْلَونَنَ) سورة يُونس: 9 ، ، بسكون نون تتبعان ('). وهكذا ظهر لنا-جليًا-كيف اهتم النحاة بالقراءات القرآنية وخدموها واهتموا بها واعتمدوا عليها في التقعيد النحوي والخلاف النحوي. المحور الثالث بيان أثر القراءات القرآنية في التقعيد النحوى سواء على مستوى المصطلح النحوي أو على مستوى الالالة التي أضافتها للقاعدة. سنحاول في هذا المحور بيان الآثار التي عادت على القاعدة النحوية من الاعتماد على القراءات القرآنية في التقعيد النحوي، وأهمها هو إدخال الجانب الدلالي في القاعدة ؛مما أكسب القاعدة ثراءً وقوةً والتصاقًا بالنص ،الذي هو هدف القاعدة من أجل الحفاظ عليه، وإضافة لذلك إدخال مصطلحات جديدة على المصطلحات المتعارف عليها -كما سيظهر مصطلحات تغلب عليها النصية والدلالية، لا النظرية والمصطلحات المجردة، فثلً على مستوى المصطلحات نلاحظ عند تتاول العلماء للقراءات القرآنية بالإعراب أو بالتوجيه غلبة مصطلحات خاصة بالقراءات تغلب عليها النصية والدلالية على المصطلحات المشهورة لدى النحاة، كما في: - - مصطلح "المبتدأ" حيث عرفه ابن هشام بأنه"الاسم المجرد عن العوامل مل اللفظية للإسناد "(Y)، والمبتدأ نوعان مبتدأ له خبر 


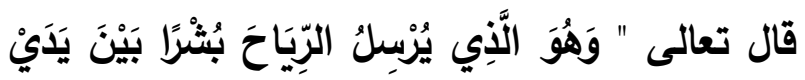

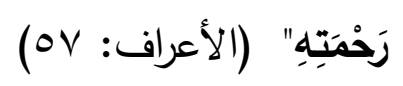

جاء في توجيه كلمة"بشرًا" والقراءات الواردة فيها وخاصة قراءة"نثرًا" أنها تحتمل أن تكون مفعولاً مطلقًا أو حالًا؛ مما وسع المعاني المحتلة في الآية

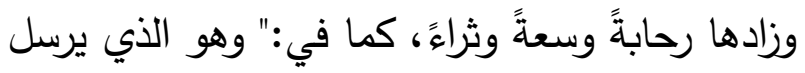

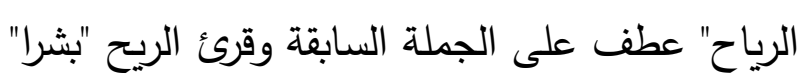
تخفيف بشر جمع بشير أو مبشرات، وقرئ بفتح الباء على أنه مصدر بشره، بمعنى باشرات أو للبشارة، وقرئ نشرا بالنون المضمومة جمع نشور، أي: بأي: ناشرات ونشرًا على أنه مصدر في موقع الحال

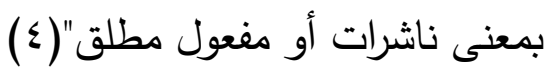

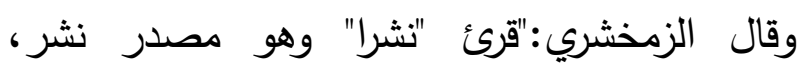
وانتصابه إما لأن "أرسل" و "نثر" متتقاربان، فكأنه

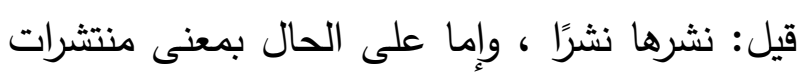

لأن المفعول المطلق هو الدصدر الفضلة المتسلط عليه عامل من لفظه كضربت ضربا لفان أو من معناه ك"قعدت جلوساً "، وقد ينوب عنه غيره ك" ضربته سوطا"، وقد تتصب أشياء على الدفعول المطلق وإن لم تكن مصدرًا،وذلكلك على سبيل النيابة عن الفن المصدر، نحو: "كل" و"بعض" مضافين إلى لى لئل

المصدر" (†) (")
ومن أمثلة ما جاء على هذا الصصطلح وكلام علماء

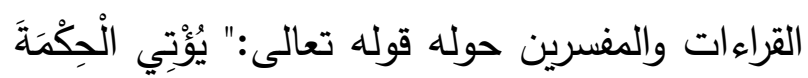

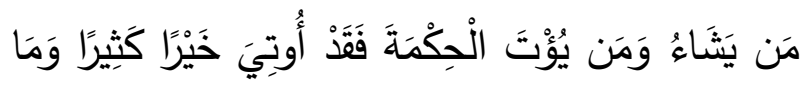

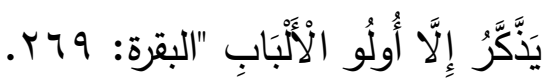
حيث "قرئ على البناء للفاعل، أي: ومن يؤته الله الحكمة والإظهار في مقام الإضمار الاعتناء بشأنها وللإشعار بعلة الحكم"فقد أوتي خيراً كثيرا" أي أي الأي خير كثير فإنه قد خير له خير الدارين "وما يذكر"، ألهائ

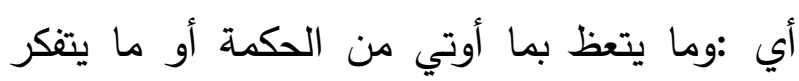

فيه" (1) (1)

وجاء عن القرطبى أنه قال: "إن مَن أعطي الحكمة

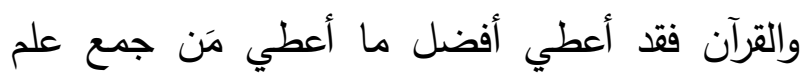
كتب الأولين من الصحف وغيرها "( (؟) وقرأ الجمهور "يؤت" مبنيا للمفعول الذي لم يسم "لالمي فاعله، وهو ضمير "مَن" وهو الدفعول الأول، لئن والثاني: "الدكمة "، وقراً ابن مسعود "يؤته"'"إِثبات الضمير الذي هو مغعول" (َ). أما الآثار والفوائد التي أضافها الاعتماد على التى القراءات القرآنية في التقعيد النحوي على مستوى التان إدخال الجانب الدلالي في القاعدة؛ مما أكسب النبآي القاعدة ثراءً وقوةً والتصاقًا بالنص فيظهر في لفاعة فئان

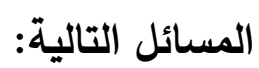

$$
\begin{aligned}
& \text { (1) إرشاد العقل السليم إلى مزايا القرآن الكريم، مرجع سابق،جا، }
\end{aligned}
$$

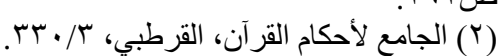

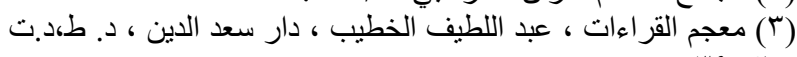

$$
\begin{aligned}
& \text {. }
\end{aligned}
$$


مع الإضافة إلى ضميرهما عليهما السلام لتحريك سلسلة الإجابة، وترك مفعول تقبل مع ذكره في قوله الإصله

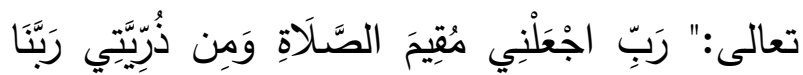

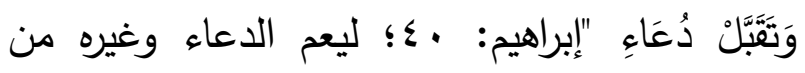

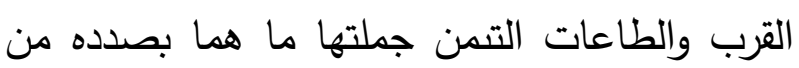

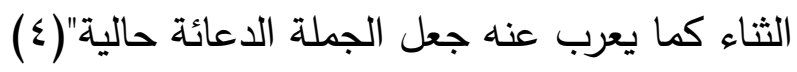

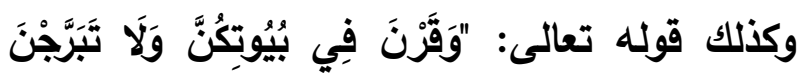

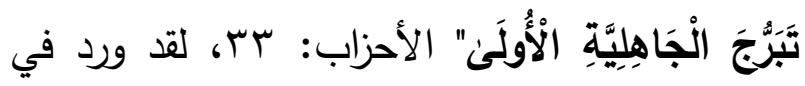

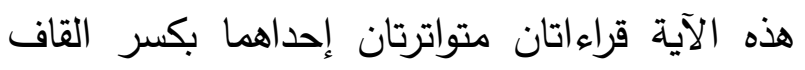

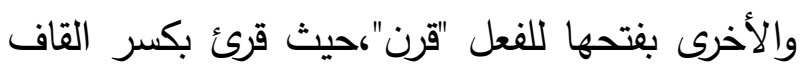

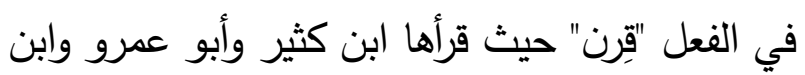

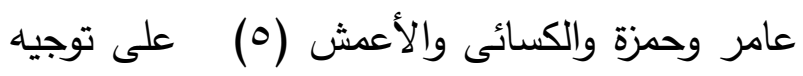
(T): وقرئ بكسر القاف من وقر يقر وقارا ، إذا ثبت

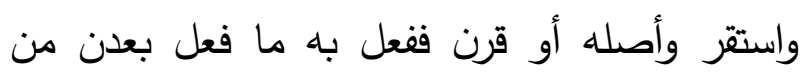

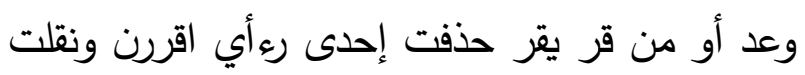

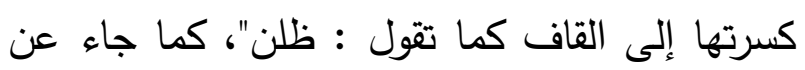

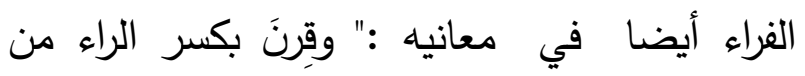

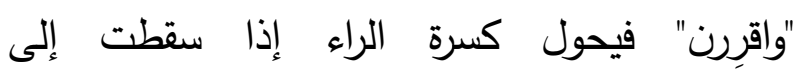

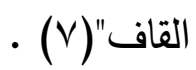
أما قراءة الفتح: فوجهها أبو السعود بقوله " أمر من

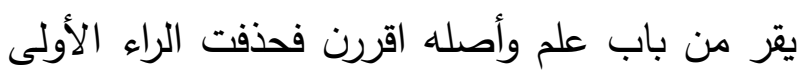

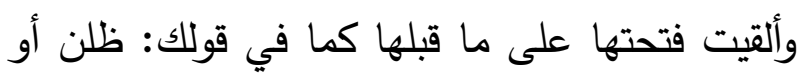
من قار يقار إذا اجتمع"(^)

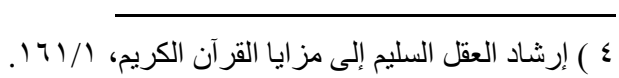

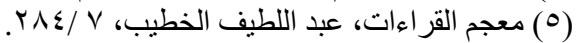

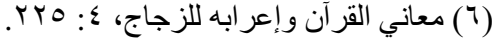

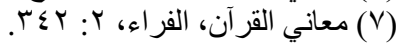

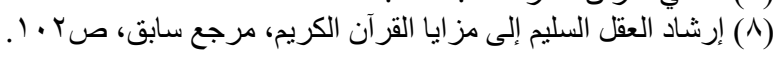

ومرتبط بهذه القضية من احتمالية الآية للحال والثراء الذي عاد النص القرآني من هذه الاحتمالية

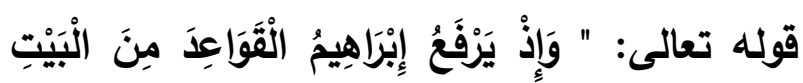

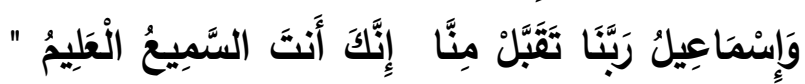
البقرة: V V I ا، يقول الزمخشرى "ربنا: أي يقولان ربنا، وهذا الفعل في محل النصب على الحال، وقد أظهره عبد الله في قرءاته، ومعناه: يرفعانها قائلين ربنا "( (1)، والقراءة بزيادة الفعل "ويقولان " أي" ويقولان:

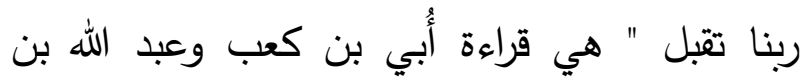
مسعود (Y). وقال أبو حيان :" ربنا تقبل منا " أي يقولان ربنا تقبل منا ، وقد قرئ به والجملة حال منهما"(r). وتفصيل هذا التوجيه ببيان وجهه النحوي والدلالي جاء عن أبي السعود بقوله :"وقد قرى به به على أنه

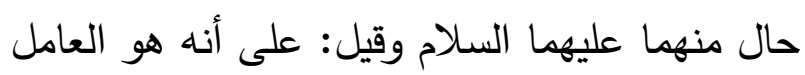
في إذ، والجملة معطوفة على ما قبلها والتقدير ويقولان ربنا تقبل منا إذ يرفعان أي وقت رفعهما، إدها، وقيل: وإسماعيل مبتدأ خبره قول محذوف، ولان وهول العامل في " ربنا تقبل منا" فيكون إبراهيم هو الرافع

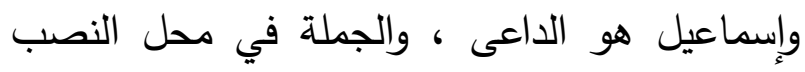

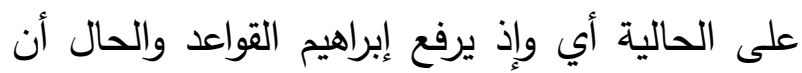
اسماعيل يقول: ربنا تقبل منا. والتعرض لوصف التف

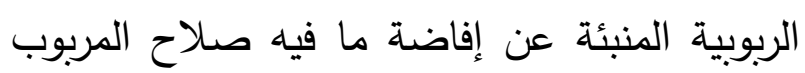

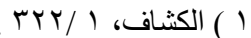

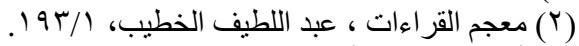

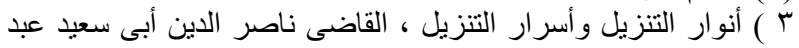

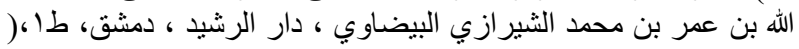

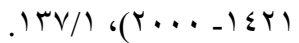


الهتمام النحاة المتأخرين بالقراءات القرآنية أكثر

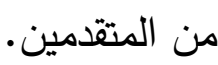
تقديم الشعر والأقيسة العقلية على القراءات

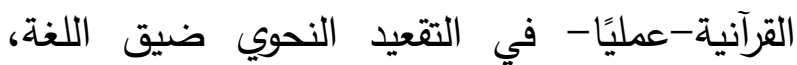
وأثقل النحو العربي بخلافات كثيرة. الاعتماد على القراءات القرآنية في التقعيد النحوي

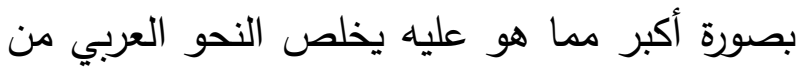
خلافات كبيرة أثقلته، ويوسع آفاق اللغة وقواعدها.

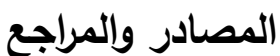

إتحاف فضلاء البشر في القراءات الأربعة عشر، شهاب الدين البنا الدمياطي، تحقيق: أنس النس مهرة، دار الكتب العلمية، بيروت، طس، 7 . . Y.

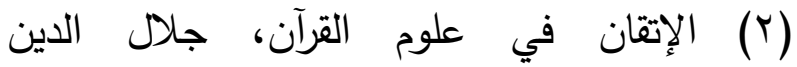
السيوطي، الهيئة المصرية العامة للكتاب، القاهرة،

$.19 \vee \leqslant 6$ b

(r) إرشاد العقل السليم إلى مزايا القرآن الكريم، أبو إ. السعود محمد بن محمد العمادي، دار إحياء، التراث

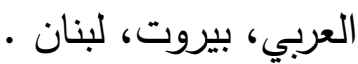

الاستشهاد والاحتجاج باللغة، د. محمد عيد، الطبعة الثالثة، عالم الكتب، القاهرة، 911 ام. (0) إصلاح المنطق، لابن السكيت، المحقق: أحمد محمد شاكر وعبد السلام هارون، دار إحياء التراث العربي، بيروت، 9 \9 ام. (T) إعراب القرآن، أبو جعفر النحاس، دار الكتب

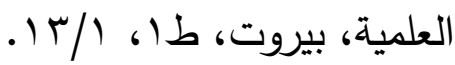

قراءة الفتح أي "وقرن" وهي قراءة أبو جعفر وعاصم

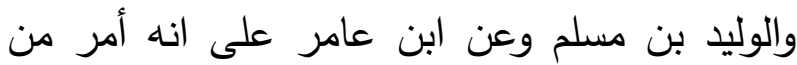
قررن يقررن (1). وهكذا خدت القراءات القرآنية اللغة بأن وسعت جذورها اللغوية وأحييت بعض اللهجات عن قبائل العرب، وزادت من المعاني المحتملة للنص القرآني. الخاتمة

نخلص من هذا البحث بهذا التتاول إلى النتائج

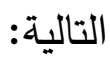
• الأهية الكبيرة للقراءات القرآنية في الدرس اللغوي عامة، والتقعيد النحوي خاصة. وقوع النحاة في تناقض كبير بين موقفهم النظري من الاحتجاج بالقراءات القرآنية، وموقفهم التطبيقي دوني من رفض بعضها أو تضعيفها.

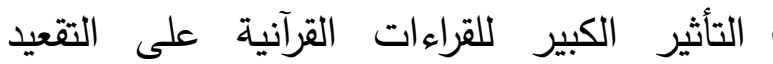
النحوي سواء على مستوى المصطلح النحوي أو على مستوى الدلالة التي أكسبتها للقاعدة وزادت من ثرائها

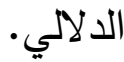
الاعتماد على القراءات القرآنية أكثر في التقعيد النحوي يفتح آفاقًا رحبة للدرس اللغوي بكل مستوياته الصوتية والصرفية والنحوية والدلالية. • يجب على الدرسات المستقبلية إعطاء أولوية أكبر لدور القراءات القرآنية في التقعيد النحوي على لتى التيه

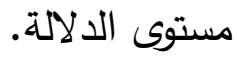


(10) البحر المحيط في التفسير، أبو حيان محمد بن يوسف الأندلسي، تحقيق: صدقي محمد جميل،

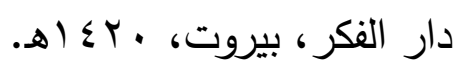

(7 (1) البرهان في علوم القرآن، بدر الدين محمد بن

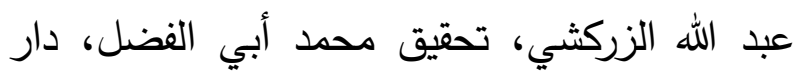
إحياء الكتب العربية، منشورات عيسى البابي الحلبي، لركي،

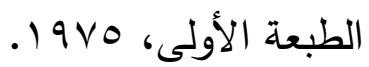
(IV) بغية الوعاة في طبقات اللغويين والنحاة، جلال

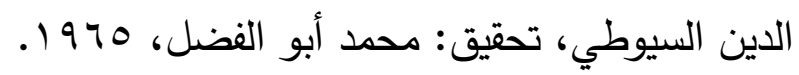
(1) البيان والتبيين، الجاحظ، تحقيق: عبد السلام هارون، مكتبة الخانجي، الطبعة الخامسة، 0 ـ ـ أهـ. (9 1) تاريخ آداب العرب، مصطفي صادق الرافعي،

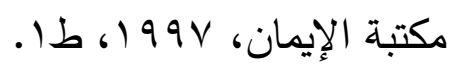

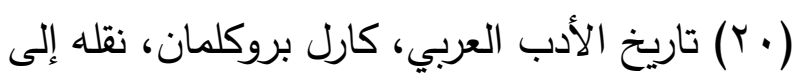

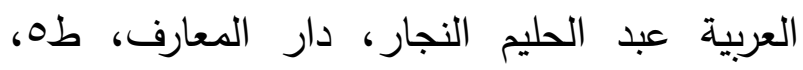

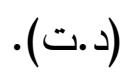

(Y) التبيان في إعراب القرآن، أبو البقاء العكبري،

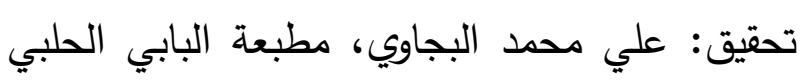
وشركاؤه، المقدمة. (Y ) التبيان في تفسير القرآن، أبو جعفر محمد بن (Y)

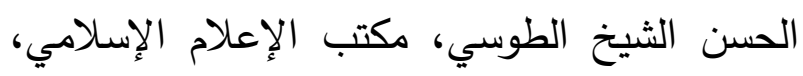
$.1 Y .9$

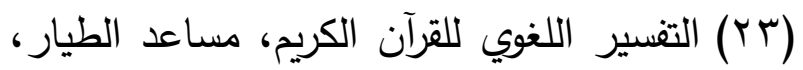

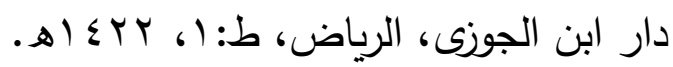

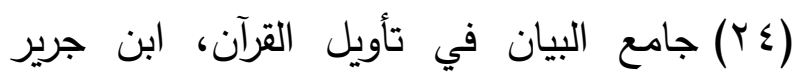
الطبري، تحقيق: د. عبد الله بن عبد المحسن
د إعراب ثلاثين سورة من القرآن الكريم، الحسين (V) بن أحمد بن خالويه، دار ومكتبة الهلال، بيروت، .1910 الأغاني، أبو الفرج الأصفهاني، مطبعة دار

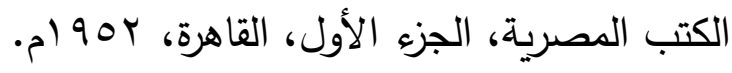
(9) الإغراب في جدل الإعراب، ابن الأنباري، تحقيق سعيد الأفغاني، ط، الجامعة السورية، دمشق، الإعراب، الإباري،

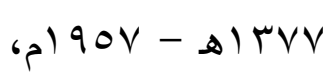
(·) (الاقتراح في علم أصول النحو، جلال الدين السيوطي، تحقيق أحمد سليم الحمصي ومحمد أحمد الحد

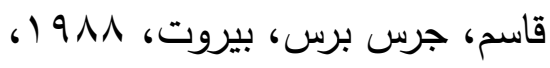

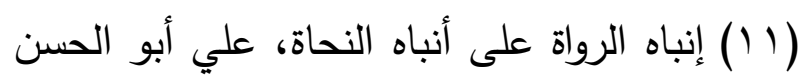

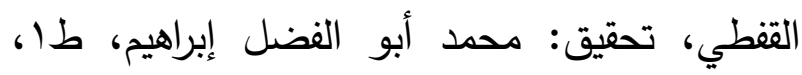
.1914 (Y (1) الإنصاف في مسائل الخلاف بين النحويين

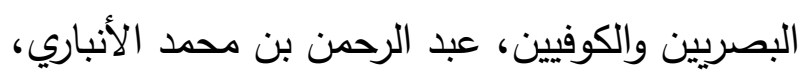
دار الفكر ، بدون تاريخ.

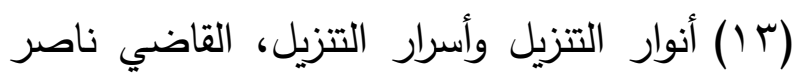
الدين أبي سعيد عبد الله بن عمر بن محمد الثيرازي

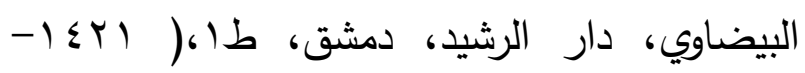
. (r...

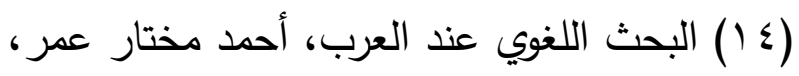

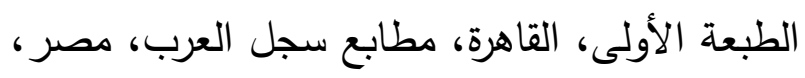
$.019 \times 1$ 
الرحمن السيد و د/ بدوى المختون - ط دار هجر - .

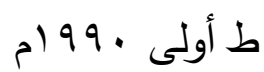

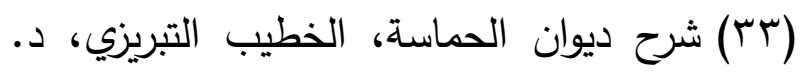
ط، عالم الكتب، بيروت، د.ط، 1997 19 1.

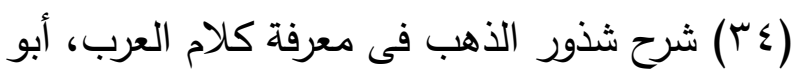

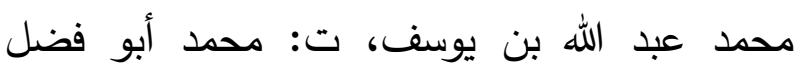

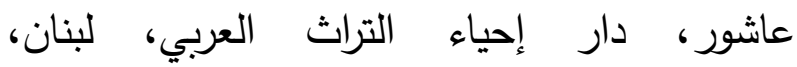

$$
\text { ط. l) }
$$

(ro) شرح قطر الندى وبل الصدى، جمال الدين بن

هشام الأنصاري، دار الخير، المدينة المنورة، د.ط.

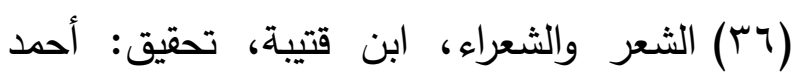

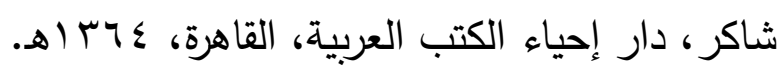

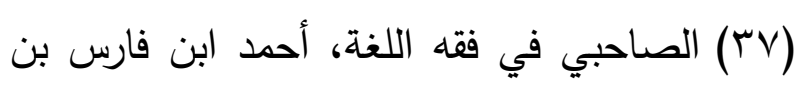
زكريا الرازي، تحقيق: أحمد حسن بسج، دار الكتب

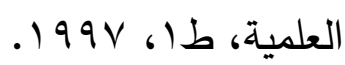

(بر) صبح الأعشى في صناعة الإنشا، أحمد بن علي القلقشنى تحقيق: يوسف علي الطويل، الكتب الاعب التبا،

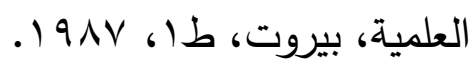

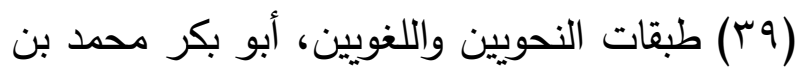

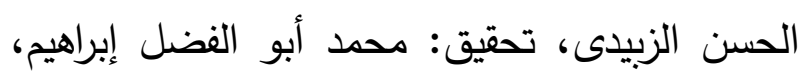

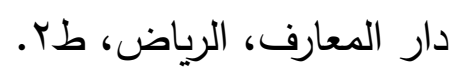

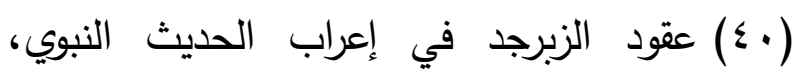
جلال الدين السيوطي، تحقيق سلمان القضاة، دار العربرجاب

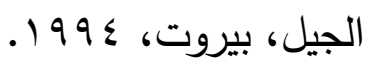

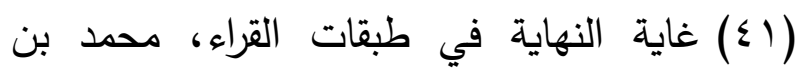
الجزري، مكتبة ابن تيمية، ط اهـ اله الهـ
التركي، دار هجر للطباعة والنشر والتوزيع

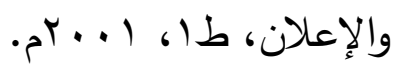

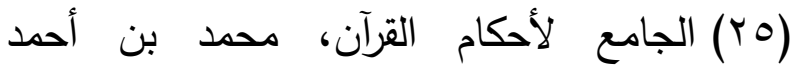

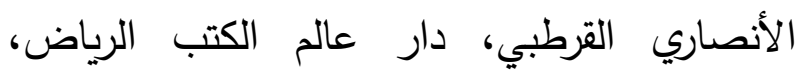
.r..r (TYY) خزانة الأدب ولب لباب لسان العرب، عبد

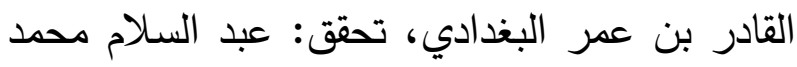
هارون، دار الكتاب العربي للطباعة والنشر ، (د.ط)، $.19 \vee 9$ تحقة) (YV) تحقيق: محمد علي النجار، دار الكتب، القاهرة،

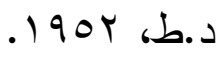

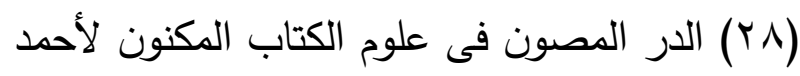
بن يوسف المعروف بالسمين الحلبي، ت ل104هـ تحقيق د / أحمد محمد الخراط - ط دار القلم دمشق بوسن بهن

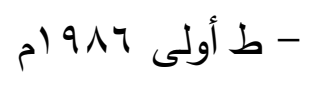

(Y9) درة الغواص فى أوهام الخواص للقاسم بن على الحريرى - تحقيق محمد أبو الفضل إبراهيم -

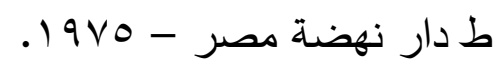
(ץ) دور الكلمة في اللغة، ستيفن أولمان، تحقيق: كمال بشر، الناشر: دار غريب للطباعة والنشر، لونه $.199 \mathrm{~V}$

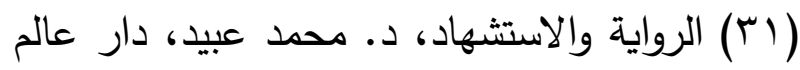

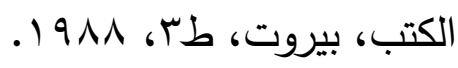

(rr) شرح التسهيل لأبى عبد الله محمد بن جمال

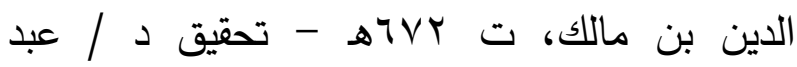




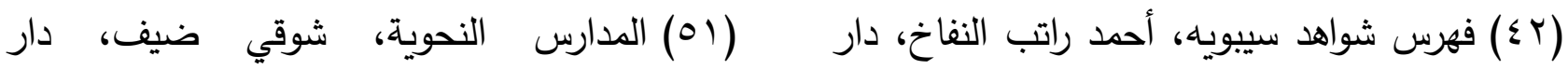
المعارف، مصر طب، (د.ت).

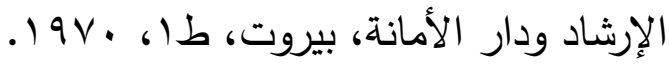

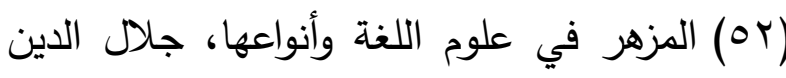

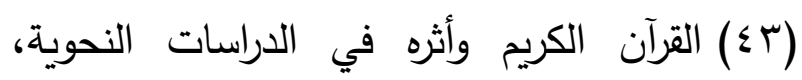

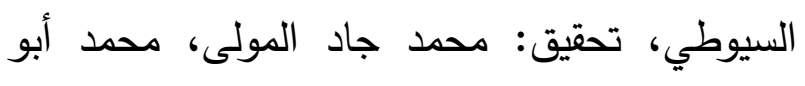

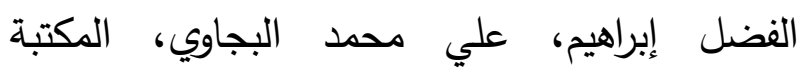

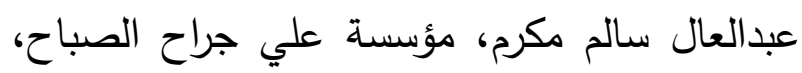

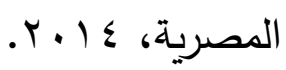

(به) مسائل خلافية بين سيبويه والخليل، فخر

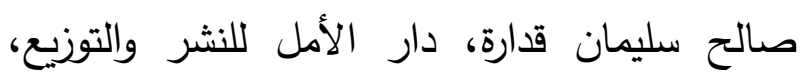

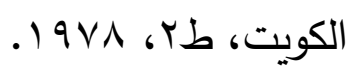

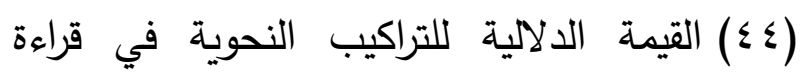

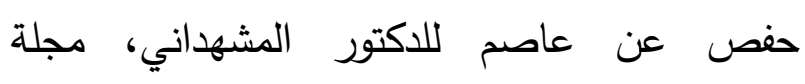

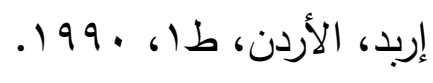

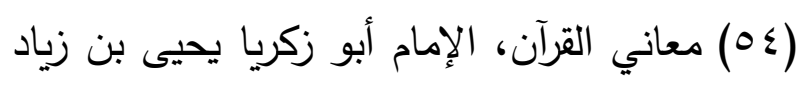

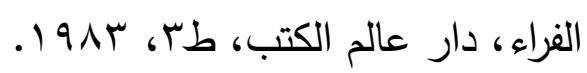

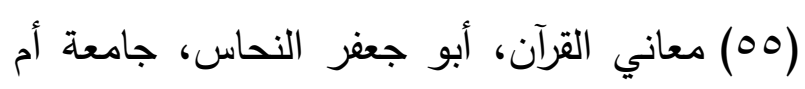
القرى، مكة المكرمة، طا. (70) معجم القراءات، عبد اللطيف الخطيب، دار

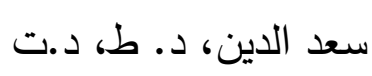

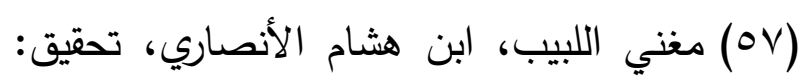

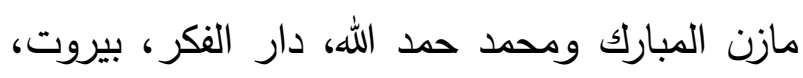

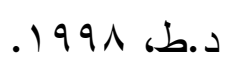
(01) مفاتيح الغيب (التفسير الكبير)، فخر الدين

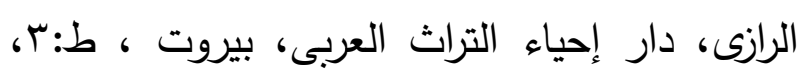
. (هو) المفصل في تاريخ النحو، د. محمد خير

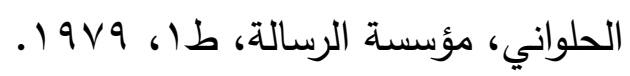

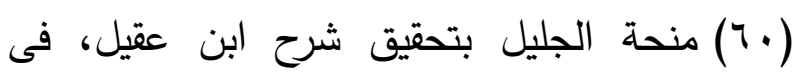
هامش شرح ابن عقيل، عبد الله بن عقيل العقيلي المصباح العدد · 1. عن عاهن (أ)؛ الكثاف عن حقائق غوامض التنزيل وعيون

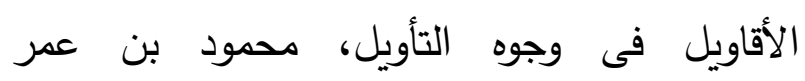

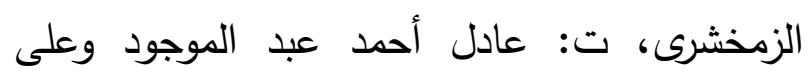

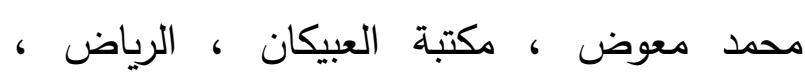
. (1991-1 (1)

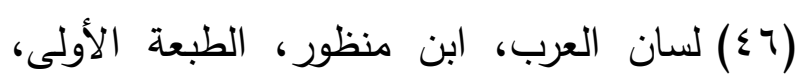

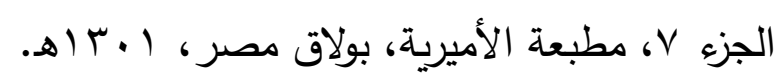

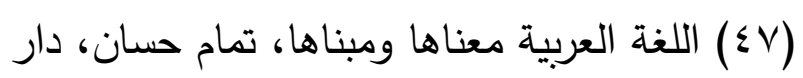
الثقافة، الدار البيضاء، طع 99 ام.

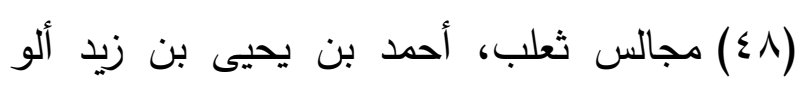

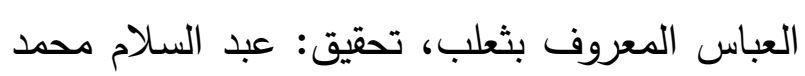

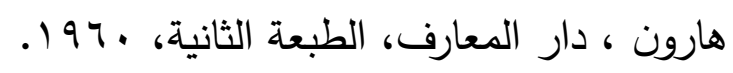

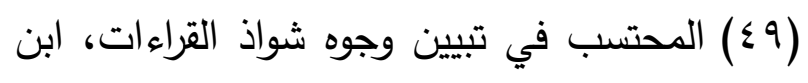

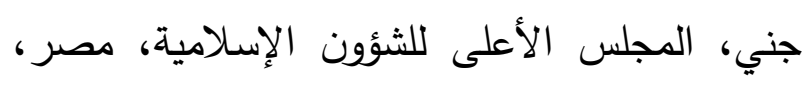
ط: 999 (0) مختصر في شواذ القرآن من كتاب البديع،

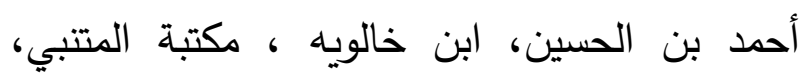

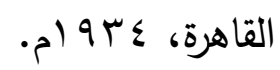




$$
\text { حامد صبحي محمد حامد "السيوطي" }
$$

i).

بهاء الدين، تحقيق: محمد محي الدين عبد الحميد، (Tآ) نوادر اللحياني في اللغة والمأثور عنه، لأبو الحسن علي بن حازم اللحياني، مؤسسة حمادة دار التراث، دار مصر للطباعة، .919 1.

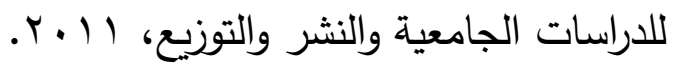

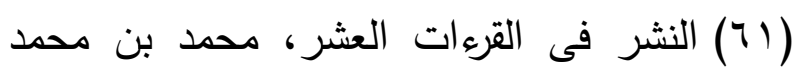

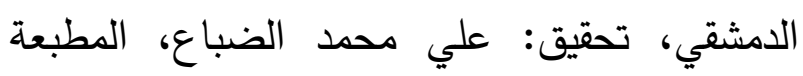
التجارية الكبرى، لابن الجزرى. 


\title{
Quranic Recitations and Grammar Correction: A Critical Analysis Study
}

\author{
Hamed Sobhi Al-Suyuti
}

\begin{abstract}
Qur'anic readings and their role in grammatical complexity, and shows the extent of contradiction between the grammarians between their theoretical stance of invoking the readings and their applied attitude towards the response of some readings, weakening some, and presenting poetry and mental measures to the Qur'anic readings in the process of grammar complexity.

Then, the research showed the usefulness of the Qur'anic readings of the grammatical base and the extent of the spaciousness and capacity that returned to the grammatical base and the language in general from relying on the Qur'anic readings.
\end{abstract}

